\title{
Televizyon Haber Bültenlerindeki İşaret Dili Çeviri Hizmetine Yönelik Sağır Topluluğun Tutum ve Beklentileri
}

\author{
Attitude and Expectations of the Deaf Society for Sign Language Translation Services \\ in Television News Bulletins
}

Araştırma/Research

Caner DOĞAN

TRT Genel Müdürlüğü Proje Mühendisi, renac14@gmail.com, ORCID ID: orcid.org/0000-00030195-0932

\section{ÖZET}

Sağırların, işitme ve görme engellilerin yayın hizmetlerine erişiminin iyileştirilmesine ilişkin usul ve esaslar hakkındaki RTÜK yönetmeliği, 2019 yılı Ekim ayında Resmî Gazete'de yayımlanmıştır. Söz konusu yönetmeliğe göre, yayıncı kuruluşlar ana haber bültenlerinden birini günlük olarak işaret diliyle yayımlamaları gerekmektedir. Türkiye'de 5'den fazla televizyon kanalı, işaret dili çevirmenliği ile haber yayınlamakta ve bunu Sağır bireyler için erişilebilir, kamu erişilebilirlik biçimlerinden biri haline getirmektedir. Görsel - İşitsel Türk İşaret Dili Çevirmenliğinin ülkemizde arzu edilen oranda yaygın olmadığı bilinmektedir. Bu boşluğu doldurmak için sağır bireylerin televizyon içeriklerine erişmeleri konusunda seçenek sunulması gerekmektedir. Bu çalışmanın amacı ülkemizdeki televizyon haber bültenlerindeki Türk Işsaret Dili çeviri hizmetlerinin hem teknik hem de çeviri kalitesi açısından değerlendirilmesi ve toplumdaki sağır bireylerin beklentilerinin belirlenmesidir. Televizyon haber bültenlerinin Türk İşaret Dili çevirilerinde, Sağır topluluğun çevriyi kavramasını olumsuz etkileyen faktörleri belirleyen bu çalışmada, veri toplamak amacıyla yapılan araştırma sürecinde çalışmaya gönüllü olarak katılan 1068 sağır bireye toplam 79 sorudan oluşan anket uygulanmıştır. Çalışmada çevrimiçi anket yöntemi kullanılmış olup alınan yanıtlar değerlendirilmiştir. Araştırma sonucunda, Sağır izleyicinin işaret dili tercümanlarının çevirilerini anlamakta zorlandığı tespit edilmiştir. Bu analiz, çevirmenlerin Türk işaret Dili akıcılığındaki eksikliklerinin Sağır bireylerin daha az anlamalarına sebep olduğuna katkıda bulunmuştur. Hedeflenen amaca ulaşılmadığı sonucuna varılmıştır. Bu sonuca göre ülkemizdeki Sağır bireylerin beklentileri karşılanamamaktadır. 
Anahtar Sözcükler: Türk İ̧aret Dili, Türk İşaret Dili Çevirmenliği, Türk İşaret Dili Çevirisi, televizyon haberleri, görsel-işitsel çeviri

\begin{abstract}
The RTÜK regulation on the procedures and principles regarding the improvement of deaf, hearing and visually impaired access to broadcasting services was published in the Official Gazette in October 2019. According to the said regulation, broadcasting organizations are required to broadcast one of the main news bulletins daily with signed language. More than 5 television channel in Turkey, broadcasts news with sign language interpreting making it accessible to deaf individuals, thus making it one of the forms of public accessibility. There are concerns about whether Turkish Sign Language interpreting for news broadcasts is at the highest standard it could be. In order to fill this gap, providing options for deaf individuals to access television content and their evaluation on the quality of the service provided should be considered. The purpose of this study is the evaluation of Turkish Sign Language translation services in television news bulletins in our country in terms of both technical and translation quality and determining the expectations of deaf individuals in the society. In this study, which aims to determine the factors that negatively affect the Deaf community's understanding of the TiD translation of television news bulletins, a questionnaire consisting of a total of 79 questions was applied to 1068 deaf individuals who voluntarily participated in data collecting of the research process. Online survey method was used during the study and the responses given accordingly were evaluated. As a result of the research, it was determined that the Deaf audience had difficulty in understanding the output of the Turkish Sign Language interpreters. This analysis showed that there was a lack of the interpreters Turkish Sign Language fluency that resulted with the Deaf individuals being unable to understand, in this respect this study has contributed to finding the reason of the problems in TiD interpretations. Thus it was concluded that the targeted goal of conveying information to the Deaf was not reached. According to the results of this study, the expectations of Deaf individuals in our country are not being met.
\end{abstract}

Keywords: Turkish Sign Language, Turkish Sign Language Interpreting, television news, audiovisual translation

\title{
1. Giriş
}

Son yıllarda çeviribilim bünyesinde sağır/işitme engelli bireyler için çeviri yöntemleri ve teknikleri geliştirilmiş ve uygulanmaya başlanmıştır. Dünyanın diğer ülkelerinde bu alanda yapılan bilimsel çalışmalar örneğin işaret diliyle görsel-işitsel çeviri, sağırlar ve işitme engelliler için altyazı çevirisi gibi çeviri türleri konusunda çalışmalara oranla ülkemizde yapılan çalışmalar ve kaynaklar oldukça sınırlıdır. Bu alanda yapılacak araştırmalar, çeviribilim açısından olduğu kadar sosyal ve toplumsal açıdan da önemlidir.

Ülkemizde ise, uzun zamandan beri uygulanan işaret dili ile görsel-işitsel çeviri ile ilgili araştırma sayısı, diğer ülkelerde yapılan araştırma sayılarından daha azdır (Okyayuz, 2019a). Erişimi kolaylaştıran çeviri türlerinden birkaçı, işitme engelliler için altyazı tekniklerinin geliştirilmesi, sağır/işitme engelli bireyler için işaret dili çevirisinin görsele eklenmesi ve canlı altyazı çevirisi olarak sıralanabilir.

Birleşmiş Milletler Engelli Hakları Sözleşmesi'nde ve yürürlük tarihi 15.11.2010 olan, Avrupa Birliği Engellilik stratejisi gibi, uluslararası metinlerde engelli bireylerin de eşit fırsatlar çerçevesinde topluma ve ekonomiye katılım hakkının olduğu net olarak 
belirtilmiştir. 11.11.2007 tarihli Avrupa Birliği yönetmeliği ve 10.03.2010 tarihli GörselIşsitsel Medya Hizmetleri Yönergesinde de medya erişiminin önemi belirtilmiştir. AB yönetmeliğinin 64. maddesinde, engelli kişilerin sosyal yaşama katılımını sağlamak için erişilebilir medya hizmetleri sunulması hususu kanunla zorunlu hale getirilmiştir. Türkiye'de de yirmi birinci yüzyılda benzer çalışmalar hız kazanmıştır.

Ülkemizin 2008 yılında imzaladığı Birleşmiş Milletler Engelli Hakları Sözleşmesinde (2006) de [A/RES/61/106], "taraf devletler engellilerin tüm iletişim araçlarını tercihlerine bağlı olarak kullanabilmesi, bilgi ve fikirleri araştırma alma ve verme özgürlüğü dâhil düşünce ve ifade özgürlüğünden diğerleriyle eşit bir şekilde yararlanabilmesi için uygun tüm tedbirleri almalıdır" hükmü yer almaktadır.

RTÜK tarafından hazırlanan, Sağır, işitme ve görme engellilerin yayın hizmetlerine Erişiminin iyileştirilmesine ilişkin Usul ve Esasları düzenleyen yönetmelik Resmî Gazetede yayımlanarak, yürürlüğe girmiştir (T.C. Resmî Gazete, 30915, 11 Ekim 2019). Yönetmelikte Yayıncı Kuruluşların "Engelli Dostu Yayınlar" yapması zorunluluk olarak tanımlanmaktadır. Buna istinaden yayınlarda işaret dili, altyazı ve sesli betimlemelerin kullanımı gerekmektedir. Bu çalışma, belirtilen gelişmelere paralel şekilde Türkiye'deki Sağır ve işitme engelli topluluğun beklentilerini ortaya koymayı amaçlamaktadır.

Hipotez ise Türk İşaret Diliyle görsel-işitsel ürünlerin çevirilerinde, belli kalite eksiklikleri gözlemlenebildiğidir. Bu hipotezi ortaya çıkaran bazı veriler vardır. Bu verilerden bazıları işaret dili ile çeviri ürününün kendisine odaklanmaktadır; örneğin, işaret dili çevirilerinin alıcılar tarafından algılanamayacak hızda sunulması. Bir başka veri kümesi ise sözü edilen çevirmenin erek dil hakimiyeti ile ilgilidir. Örneğin, el dışı işaretlerin eksik kullanılması, çevirmenin dilinin akıcı olmaması. Başka veriler ise işaret dili çevirisi etkinliği ile ilgilidir; örneğin, çevirmenin işaret alanının etkili şekilde kullanılmaması. İşaret dili çevirisinin sunumu bir başka önemli olgudur; örneğin, çevirmenin ekranda sunulduğu kutucuğun çeviri alımlamayı olumsuz etkileyecek şekilde küçük olması. Tüm bunlara ek olarak alıcı topluluk ile ilgili veriler de çalışmaya dahil edilmiştir; örneğin, Sağır topluluğun düşük okuryazarlık seviyesi ve düşük işaret dili düzeyleri. Özetle çeviri ürün, çevirmenin dil hakimiyeti ve çeviri deneyimi, çevirmenin ekranda sunuluş şekli ve alıcı topluluğun alımlama kapasitesi gibi unsurlar bu topluğunun medya çevirilerini takip etmelerini güçleştirmektedir.

Çalışmada, farklı aktörleri ilgilendiren birçok farklı etmene bakılarak Sağır bireylerin mevcut görsel-işitsel medyadan memnun olup olmadığı ve televizyonlardaki Türk İşaret Dili yapımının izleyici kitlesi tarafından ne kadar kavrandığının araştırılması amaçlanmaktadır.

Steiner (1998) televizyonlarda İngiliz İşaret Dili'nin (BSL) üretimini ve bu dilin sağır izleyiciler tarafından kavranmasını araştırmıştır. Kurz ve Mikulasek (2004) tarafından geniş bir televizyon programları için yapılan işaret dili çevirisi konusunda 17 Avrupa ülkesinde araştırması yapılmıştır. İşitme engelli çevirmenlerinin işaret dili ile haber çevirisi konusuna ise Allsop ve Kyle (2008) odaklanmışlardır. 


\subsection{Türkiye'deki Televizyon İçeriklerine Sağırların Erişilebilirliği}

Türkiye'de televizyonlar 24 yıldır Sağırlar için erişilebilir programlara ev sahipliği yapmaktadır. İlk işaret dili çevirmeni eklentili haber programı 1993 yılında TRT 1'de yayınlanmıştır, TRT-2'de yayınlanan ve 10 yıl devam eden uygulama ise 1998-2004 yılları arasını kapsamaktadır. O zamandan beri farklı kanallarda, programlarda işaret dili çevirisi sunulmuştur. Günümüzde çevirmen ile en az beş televizyon kanalında akşam ana haber bülteninde işaret dili çevirisi bulunmaktadır.

TRT kanallarında yayınlanan sinema ve televizyon için yapılmış filmler, diziler ile haber programlarında; üç yıl içinde yüzde otuza, beş yıl içinde yüzde elliye ulaşılacak şekilde işitme engellilere yönelik dilici altyazı çevirisi hizmeti seçeneğine yer verilmesi zorunlu hale gelmiştir. Aynı zorunluluk ulusal karasal yayın lisansına sahip, özel medya hizmet sağlayıcı kuruluşlar için de getirilerek, "yayınlarda üç yıl içinde yüzde yirmiye, beş yıl içinde yüzde kırka ulaşılacaktır" şeklinde düzenlenmiştir.

Her ne kadar son yirmi yıldaki tüm bu gelişmeler, Sağır topluluğunun varlığının Türkiye'de kabul edildiğini ve bu topluluğa yönelik hizmetlerin önemini kanıtlasa da bu kesimin ihtiyaçlarını karşılamak için yeterli olmayabileceği de ileri sürülebilir. Sonuç olarak mevcut medya erişilebilirlik alternatiflerinin Sağır topluluğunun beklentilerini ve ihtiyaçlarını karşılamadığı belirlenmiştir (Gökçe, 2018).

Avrupa Birliği Görsel-Işsitsel Medya Hizmetleri Yönergesi (2010) Madde 7’ye göre “...üye devletler, yargı yetkileri altındaki medya hizmet sağlayıcılarının hizmetlerini, görme ve işitme engelli kişilere aşamalı olarak erişilebilir kılmayı sağlamalarını teşvik edeceklerdir". Bu maddeden anlaşılacağı üzere dünyada ve tabi ki akademik camiada da yaklaşık yirmi yıldır artan yoğunlukta engellilerin yayınlara erişimi hakkının gerçekleşmesi için çalışmalar yürütülmektedir (örneğin bkz. Okyayuz, 2019a). Yapılan incelemeler sonucu hemen hemen tüm Avrupa ülkelerinde üç tür çevirinin; ayrıntılı altyazı ve işaret dili uygulamalarının yapıldığı görülmekte ve bu konudaki en büyük destek, engelliler ve temsilcileri ile çalışan akademik camiadan gelmektedir. Ülkeler bağlamından bakıldığında örneğin Belçika'da tüm programların \%80 oranında ayrıntılı ve/veya canlı altyazı ile verildiği görülmektedir. Bu oran Çekya'da \%70 iken Finlandiya'da 2016'da \%100 olmuştur. Macaristan'da ise dört saat altyazı ve işaret dili uygulaması ile başlamış, aşamalı olarak işaret dili arttırılmış, 2015'te ise, her program altyazı ile verilmeye başlanmıştır. 2011-2013 yılları arasında İspanya'da kamu hizmeti yayıncılarından \%50'den başlayarak \%70 ve daha sonra \%90 oranında ayrıntılı altyazı istenmiştir (Kaya, 2019). Ülkeler artan oranlarda engellilere erişim sağlamış ve böylece farklı profillerdeki vatandaşlarına hizmet götürebilmiştir.

Sağır bireylerin, Türk İşaret Dili çevirilerinden azami ölçüde yararlanamıyor olmaları, televizyona erişebilirliğin ülkemizde arzulanan seviyede olmadığını ortaya koyabilmektedir. Bu konuda daha fazla bilimsel çalışmaya ihtiyaç olduğu ise yadsınamaz. Alıcılar, televizyon yayın hizmeti sağlayıcılarının, bu hizmetlerini herkes için kullanılabilir 
hale getirmelerini ve imkânları ölçüsünde yapabileceklerinin en iyisini yapmalarını arzu edilmektedir.

Televizyondaki alternatiflerin, Sağır topluluğunun ihtiyaç ve beklentilerini ne ölçüde karşıladığı ayrıca Türkiye'deki işaret dili çevirisinin genel durumu ve mevcut hizmetlerin sağırların beklentilerini ne derece karşıladığı bu çalışmada incelenecektir.

\subsection{Sağır Topluluğu}

Sağırların kültürel kimliği (Sağır topluluğun bir üyesi olma anlayışı) genelde genç yaştaki sağırlar için okullarda edinilen ve hayatlarının geri kalanında sağır derneklere katılımla pekişen bir olgudur. Ladd'un dediği gibi, "bu geleneksel topluluk ... Sağır okullarına devam eden ve Sağır kulüplerinde veya diğer Sağır sosyal faaliyetlerinde buluşan sağırlardan oluşur" (2003, s. 44). Sağır topluluğu Baker-Shenk ve Padden tarafından "ortak bir dil, ortak deneyimler ve değerler paylaşan ve birbirleriyle ve insanlarla işitmenin ortak bir yolunu paylaşan sağır ve işitme güçlüğü olan bireylerden oluşur" şeklinde tanımlanmıştır $(1978$, s. 4).

Sağır derneklerinin yaptığı ve diğer çalışma sonuçlarına göre yaklaşık üç milyon sağır bireyin olduğu bunlardan sekiz yüz bininin Türk İşaret Dilini kullandığı sonucuna varılmıştır (Fırat, 2019). Bu verilere göre engelsiz erişim çalışmalarının nüfusumuzun yaklaşık yüzde on üçünü ilgilendirdiği sonucuna varılabilmektedir. Medyaya erişim konusunda alınması gereken hayli yol olduğu bilinmekte ve birçok hedef kitleyi kapsaması gerekmektedir.

\subsection{Görsel-İşitsel Çeviri}

Görsel - İşitsel çeviri görme ve işitme duyuları ile alımlanan ürünlerin çevirisine verilen addır. Bu alan, sinema, belgesel ve televizyon programlarının ilgili dillere çevrilmesiyle ortaya çıkmıştır. Görsel-işitsel çevirinin özellikleri şöyle sıralanabilir: hedef kitlenin alışkanlıklarının metin çevirilerinde önemli rolü vardır, kaynak kitlede oluşan yapıların, hedef kitlede anlaşılması zor olduğunda, bu durumda altyazı çevirisinden yararlanmak mümkündür. Çevirmenlere aralarında, kısaltım, çıkarma, özetleme ve uyarlama gibi pek çok açılımı olan çeviri stratejilerinden yararlanarak bir çeviri metin ortaya koyarlar (Okyayuz, 2019a). Aşağıda, görsel-işitsel çeviri ile ilgili Türkiye'deki yöntemler ve uygulamalar ile alandaki çalışmaların nitel ve nicel bir analizi de sunulmaktadır. Bu bölüm, Türkiye'deki görsel-işitsel çeviri eğitimi ve araştırmasının mevcut durumunu göstermektedir. Ayrıca, görsel-işitsel çevirmenler için standartların ve yeterliliklerin hazırlanması, medya erişilebilirliğine devletin ve toplumun ilgisinin artması ve görme engelliler için sesli betimleme, sağır ve işitme zorluğu olanlar için altyazı çevirisi, görselişitsel ürünlere işaret dili çevirisi bağlamında Türkiye'deki son gelişmelerden söz edilmektedir.

Engelsiz erişim, sağır bireylerin genel hizmetlere erişimi için işaret dili çevirisi yapılarak faaliyetlerden azami yararlanmayı sağlamak olarak tanımlamaktadır. Türk İşaret Dili çevirilerinde, başarılı sonuçlar alabilmek için, sağır toplumun kültürünün iyi 
bilinmesi ihtiyaçlarının çok detaylı öğrenilmesi gerekir. Sağır topluluğun kültürünü öğrenmeden, bu konuda geniş kapsamlı çalışma yapmadan, ihtiyaçlarını belirlemeden yapılan Türk İşaret Dili çevirileri yeterli olmamaktadır. Engelsiz erişim, Türk İşaret Dili çevirisi yapanlar ve tercümanlar alanları ile ilgili en üst seviyede eğitim almalı, ulusal ve uluslararası konferans ve kurslara katılarak kendilerini geliştirmelidir. Ülkemizde engelsiz erişim çalışmaları yaygınlaşmak ile birlikte hedeflenen sonucun kaliteli vasıflı ve donanımlı çevirmenlerin geliştirilmesi ve uzmanlaşan Türk İ̧̧aret Dili tercümanlarının artırılması gerekmektedir (Okyayuz, 2019b).

Görsel-işitsel çeviri çalışmalarında uygulayıcılarla ve sektörle işbirliğinin önemi vurgulanması gereken bir konudur. Ülkemizde bu konuda da olumlu gelişmeler yaşanmaktadır. Örneğin, Mesleki Yeterlilik Kurumu, 2020 yılında işaret dili çevirmenliği alanında görsel-işitsel alanda işaret dili çevirmenliği konusunda çalışma yapmıştır (bkz. Çeviri Derneği, 2020).

Görsel-işitsel çeviri alanında bir başka yeni açılım ise medya hizmetlerine engelsiz erişim için yapılan çeviri türlerinde yapılan girişimler ve araştırmalardır. Erişim için çeviri ifadesi, modern çeviribilimde, engelsiz erişim için çeviri yapılması anlamında, yani engelli bireylerin belli ürünlere, ortamlara ve benzerine erişimlerini sağlamak için yapılan çeviri türlerine işaret etmek için kullanılmaktadır (bkz. Okyayuz, 2019a). Çeviribilim bağlamında, bir engeli yüzünden (örneğin, görme engeli, işitme engeli) bir kaynak metne erişimi olmayan bireylere erişim sağlamak için yapılan tüm çeviri türlerini kapsar. Günümüzde engelsiz erişim için yapılan çeviri türleri, hem Türkiye'de hem de dünyanın birçok yerinde, giderek yaygınlaşmakta ve çeşitlenmektedir. Hem dil içinde hem diller arasında ayrıca göstergeler arası çeviri yapılmaktadır.

Ülkemizde söz konusu araştırmaları yapmak için bir ihtiyaç olduğu kadar bu çalışmalar ayrıca arzulanmaktadır. Dolayısıyla bir sonraki bölümde bu düşünceler ışığında Türkiye'de henüz bütün ayrıntısıyla çalışılmamış ancak dünyadaki araştırmacıların üzerinde durduğu ve farklı ülkelerde ihtiyaç duyulan (Türkiye'de de günümüzde olmasa dahi gelecekte ihtiyaç duyulacak) çalışmaların neler olabileceğinden söz edilecektir.

\subsection{Televizyonda İşaret Dili Çevirmenlerin Rolü}

Daniel Gile'ye (1995, s. 21) göre, profesyonel çevirmenlik “iletişimsel işlevli, profesyonel bir ortamda profesyonel bir amaç ile gerçekleştirilen ve bu ortamla sınırlanan bir hizmet etkinliğidir". Bu tanım, profesyonel standartlara göre, belirli bir hedef kitleye anlaşılır bir mesaj iletmek için profesyonel çevirmenin çevirinin bir hizmet olarak rolünü vurgulamaktadır. Sonuç olarak, izleyici beklentileri ve/veya yanıtları, sözlü çeviri çalışmalarının ayrılmaz bir parçasıdır. İşaret dili çevirisi için kullanıcı beklentilerini veya yanıtlarını araştıran artan sayıda deneysel çalışma bulunmaktadır (Steiner, 1998; Locker, 1990; Woll, 1991; Napier ve Barker, 2004; Kurz ve Langer, 2004; Forestal, 2005; WitterMerithew ve Johnson 2005; Kyle, 2007; Napier ve Rohan, 2007; Stone, 2009; Xiao ve Yu, 2009; Xiao ve Li, 2013). 
Ülkemizde bazı televizyon kanalları, bazı programlarında (haber, eğlence ve dizi programı gibi) CODA'ları (işitme engelli ebeveynlerin işiten çocukları) işaret dili çevirmeni olarak görevlendirdiği gözlenmektedir. İşaret dili çevirmenleri, TV ekranlarının sağ alt köşesinde gösterilerek, konuşan bir kişinin söylediklerini işaret diline çevirmektedir. Çevirmen, ayrıca işitme engelli kişilerin işaret diliyle anlattıklarını, konuşma diline çevirebilir.

İşaret dili çevirmenlerince çevrilmiş bulunduğu programı izleyen Sağır topluluğunun, televizyonu izleyen, işiten kesimle benzer çeviri problemleri yaşadıkları görülmüştür. Bu probleme hem İngiltere'de (Steiner, 1998; Woll, B. 1991; Kyle, 2007; Stratiy, 2005) hem de Çin'de (Xiao ve Yu, 2009; Xiao ve Yu, 2012; Xiao ve Li, 2013) rastlanmış olup, Kyle'nın (2007) ve Stone'un (2009) çalışmalarında da bu durumdan bahsedilmiştir.

Güney Afrika'da, işaret dili çevirmenleri, birçok TV haber yayınında yerel işaret dilini Sağır topluluğuna bir hizmet aracı olarak kullanmaktadır. Ancak araştırmalar bu izleyicilerin çevirmenlerden memnun olmadıklarını tespit etmiştir (Wehrmeyer, 2013). Yapılan çalışmalar sağır izleyicilerin, işaret dili çevirmenleri yerine altyazıyı tercih ettiklerini ortaya koymuştur. Bu çalışmalarda işaret dili çevirilerini anlama zorluğu olduğu ifade edilmiştir: Zayıf çevirmenlik becerileri, çevirmenin işaret dili becerilerinin yetersiz oluşu, tutarlı bir mesaj aktarmaya değil, bilgi aktarmaya odaklanan çevirmenler (Stratiy, 2005) başlıca sorunsallar olarak belirlenmiştir. Çeviride akıcılık olmaması, çevirmenin ekrandaki görüntüsünün çok küçük boyutlarda olması ve çevirmenlerin hızlı işaret kullanması takip edilmelerini engellemektedir (Kyle, 2007; Xiao ve Yu, 2009; Xiao ve Li, 2013). Yine Kyle'ın (2007), 1992 ve 2005 yılları arasında yürütmüş olduğu altı anketin kapsamlı araştırma sonucuna göre ise, sağır izleyicilerin çevirmenlerin kendi kullandıklarından farklı bir işaret dili kullandıkları, çevirmenlerin zayıf işaret dili becerilerine sahip olduklarını düşündükleri ve çevirmenlerin ekran görüntülerinin boyutunun küçüklüğünden memnun olmadıklarını ifade ettikleri ortaya koymaktır.

\subsection{Televizyonlarda Sağır Çevirmenleri}

Televizyonlarda Sağır çevirmenlerin tarihsel rolü, Sağır çevirmenin kullandığı çeviri tarzını belgelendirir; günümüz Sağır çeviri normunun habercisidir. Çeviri yasası, inşa edilen izleyici kitlesi ile ilgili olmalıdır (Ruuskanen, 1996). Bu, sağır çevirmen için, bu sınırlı rolün, işiten çevirmenden daha verimli olduğunu gösteriyor. Sağır çevirmeni yayın haberlerinde daha fazla ajans istemektedir (Rudvin, 2002).

Sağır çevirmenin topluluktaki temel üyelerinin farkındadır. Bu, Sağır topluluğunda doğup büyümektedir. Sağır çevirmeni, Sağır topluluğu ile hâlâ sosyalleşmektedir, çünkü bu onların ev topluluklarıdır. Ayrıca, Sağır çevirmen kimliğini ve dillerini, topluluklarının diğer üyeleri tarafından anlaşılacak şekilde değiştirmekte güçlendirmektedir. Dolayısıyla doğallık kavramları, Sağır çeviri normunun önemli bir parçasıdır ve bu toplulukta büyümekten ve dilde doğal olarak akıcı olmaktan gelmektedir (Stone, 2007). 
Belçika'da devlet kanalı olan Vlaamse Radio Televizyon (VRT) kanalında sağır çevirmenler bulunmaktadır. Ayrıca "Iş̧aret Dili Birimi" adıyla ayrı bir bölüm vardır. Bu bölümde sağır ve işiten çevirmenler bulunmaktadır. Belçika'da Felemenkçe işaret dili kullanılmaktadır.

İngiltere'de, küresel yönetilen medya hizmetleri şirketi olan RED BEE'de Sağır çevirmenleri bulunmaktadır. Sağır çevirmeler canlı programlarda eşzamanlı çeviri yapmaktadır. İşaret dili çevirisi stüdyoda bulunan telepromptere bakarak sunulmaktadır.

Almanya'da medya alanında Sağır tercümanlarda bulunmaktadır. Skarabe şirketinde, Sağır ve işitme güçlüğü çeken bireyler için Sağır çevirmenler işaret dilinden çeviri yapmaktadır. Ayrıca kamu hizmetli yayıncısı olan ARD ve ZDF televizyon kanalları ortaklaşa işletilen bir ücretsiz televizyon kanalı olan Phoenix TV kanalında Sağır çevirmenler bulundurmaktadır.

\section{Yöntem}

Bu çalışma, Türkiye'deki Sağır topluluğun televizyon haber bültenlerindeki işaret dili çeviri hizmetlerine yönelik tutum ve beklentilerine öncü bir yaklaşım sunmaktadır. Aşağıdaki bu sorulara cevap bulmak için ankette tasarlanmıştır.

(1) Resmi ve özel medya hizmet sağlayıcı kuruluşların eylemleri yeterli düzeyde midir?

(2) Bu eylemler Sağır topluluğun ihtiyaç ve beklentilerini karşılıyor mu?

Bu sorulara sağlıklı cevap bulmak için televizyonun Sağır topluluğun beklentilerini karşılayıp, karşılamadığını görmek ve anlamak için bir anket yöntemi benimsenmiştir.

Araştırma modelinde bulunan değişkenler arasındaki ilişkileri yansıtan varsayımları test etmek amacıyla ihtiyaç duyulan veriler tanımlayıcı bir araştırma tasarımı çerçevesinde toplanmıştır. Bu araştırmada evrenimiz Türkiye'de ve yurt dışında yaşayan Türk Sağırlardır. Geniş bir örneklem ulaşma gerekliliği nedeniyle veri toplama aracı olarak anket tercih edilmiştir. Anket formu Google Formlar aracılığı ile online olarak uygulanmıştır. Anket formu düzenlemek ve katılımı artırmak amacıyla iki hafta arayla hatırlatıcı bildirimler (Instagram, Facebook vb.) yapılmıştır.

Sağır topluluk ankete yoğun bir ilgi göstermiş olup Türkiye'nin 81 ilinin tamamında ankete katılım bulunmaktadır. Bu süreç sonunda, katılımcılar tarafından doldurulan 1152 anket ön incelemeden geçirilmiş ve 1068 anket analiz için uygun görülmüştür.

Anket, yedi bölümden oluşmaktadır. Birinci bölümde, demografik özellikleri ile ilgili sorular yer alıp, katılımcılarda oluşan kişilik özelliklerine ilişkin 17 adet soru 5'li likert ölçeği şeklinde oluşturulmuştur. Çalışmanın bağımsız değişken grubu, kişinin cinsiyeti, yaşı, eğitim durumu, oturduğu şehir, işitme cihazı kullanımı, işitme kaybı zamanı, TíD kullanımı/deneyimi, TiD ve Türkçe (okuryazarlık) yeterliliği, ailede işitme engelli sayısı, Sağır toplulukla ilişkisi gibi demografik özelliklerinden oluşmaktadır. İkinci bölümde yer alan, araştırma modelinde televizyon tercihlerine ilişkin ifadeler bulunmaktadır. Günlük 
izlenme saati, izlenen televizyon programları, günlük haber programı takip etme oranı ve zaman aralığı, televizyon kullanımı ve türleri gibi konuları içine almaktadır. Üçüncü bölüm; katılımcıların işaret diline yönelik tutum bilgileri ile ilgili soruları içermektedir. Dördüncü bölüm haber çevirisine ilişkin teknik beklentilerini sağlayan 12 sorudan oluşmaktadır (çevirmenin ekranda kapladığı alan, arka planı, kıyafet seçimi. vb.). Anket formunun beşinci bölümde haber çevirisine ilişkin içeriksel beklentilerini sorgulayan 5 soru yer almaktadır. Tüm sorular 5 noktalı Likert ölçeğine göre hazırlanmıştır.

Anketin altıncı ve yedinci bölümünde, katılımcılara işaret dili çevirisini en çok beğendiği ve hiç beğenmediği, televizyon kanalı ve akşam saatlerinde çıkan ana haber programından tercih ettikleri kanallar, TiD Tercümanlarının haber çevirisine ilişkin faktörlerinin yer aldığı 5'li Likert ölçeğine uygun oluşturulan 15 soruya yer verilmiştir. (TiD yetkinliği, TiD akıcılığı, TiD dilbilgisini doğru kullanması, çevirdiği kişinin duygu durumunu temsil etmesi vb.).

Ankette yer alan seçenekler "katılma" ile "sıklık" dereceleri adı verilen iki farklı şekilde hazırlanarak verilmiştir. Katılma derecesinde seçenekler "katılıyorum", "kararsızım", "kesinlikle katılmıyorum" vb. şeklinde sıralanırken; sıklık derecesinde: "4-7 yıl”, "2-3 saat" gibi şeklinde sıralanmıştır. Okuryazar seviyesi yeterli olmayan Sağır bireylerin soruları daha etkin şekilde anlamaları için her sorunun Türk İşaret Dili (TID) çeviri videoları eklenmiştir (bkz. https://www.youtube.com/watch?v=aynx0nFuUZO). Ayrıca soruların yazımı da, TiD uyumuna uygun olarak hazırlanmıştır (örneğin, Türkçe: Lütfen bir günde ortalama televizyon izleme saatinizi belirtiniz. TiD: Bir gün TV kaç saat izlemek?)

Anketin hazırlık aşamasında, "Güney Afrika'da Televizyon Haberleri İşaret Dili Tercümanlarını Kavrama" Wehrmeyer (2015), Xiaoyan Xiao, Xiaoyan Chen ve Jeffrey Levi Palmer (2015)'in “Çinli Sağır İzleyicilerin İşaret Dili Tercümanını Televizyonda Anlamaları" çalışmasından hazırladıkları ölçek takip edilmiştir.

Anket formlarındaki sorular, kontrol listesi, çoktan seçmeli ve Likert tipi ölçek formatına göre hazırlanmıştır. Likert tipinin avantajı, her çeşit durum ve davranışlara uyum sağlayabilmesi ve ölçülebilen düzeyin hem yönünü hem de derecesini hesaplayabilme kolaylığı sağlayabilmesidir (Tavşancıl, 2006, s. 139).

Altıncı bölümdeki “iş̧aret dili çevirisinde en çok beğendiğiniz televizyon kanalı hangisidir?" sorusunu ve yedinci bölümdeki, "İ̧saret dili çevirisi ile haber program yapan, hiç beğenmediğiniz televizyon kanalı hangisidir?" sorusuna anket sonucuna örneklem yöntemiyle ulaşılmıştır.

Araştırmada tek tek verilerden yola çıkarak genel bir sonuca varılmaya çalışılmış, yani tümevarım yöntemi kullanılmıştır. Bu çalışmada tanımlayıcı-açıklayıcı yöntem kullanılmıştır. 


\section{Verilerin Analizi}

\subsection{Sağır Katılımcıların Demografik Bilgileri}

\subsubsection{Katılımcılara İlişkin Demografik Bilgiler}

Katılımcıların demografik özellikleri ile ilgili istatistikleri verileri elde etmek için frekans (katılımcı) analizi yapılmıştır. Bulgular, Tablo 1'de sunulmuştur.

Araştırmanın örneklemini oluşturan toplam 1068 katılımcıdan \%37,92'si kadın, \%62,08'i erkeklerden oluşmaktadır. Ankete katılan Sağırlara yaşının ne olduğu sorulmuştur. İlgili soruya katılımcıların verdiği cevaplar Tablo 1'deki (Yaş) verilerle sunulmuştur. Katılımcıların \%1,59'unun 12-17 yaş, \%21,44'ünün 18-24 yaş, \%42,32'nin 25-34 yaş, \%27,43'ünün 35-44 yaş, \%5,99'unun 45-54 yaş, \%0,75'inin 55-64 yaş aralığında ve \%0,47'nin 65 yaşından büyük olduğu görülmektedir. Sağırların eğitim düzeyi \%4,31'i (46 kişi) ilkokulu mezunu, \%7,02'yi (75 kişi) ortaokul mezunu, \%56,65'i (605 kişi) lise mezunu, \%16,67'yi (178 kişi) yüksekokul/ön lisans mezunu, \%13,67'i (146 kişi) lisans mezunu ve \%1,69'u yüksek lisans mezunudur. Eğitim düzeyleri incelendiğinde anket verilerine göre, çalışmaya katılan Sağır topluluğun büyük bölümünün lise mezunu olduğu görülmektedir.

Yaş dağılımının ortalaması 31,8 olan, normal bir eğrinin izlendiği ve yaş açısından temsil edilebilirliği göstermektedir.

Tablo 1

Katılımcılara ilişkin demografik bilgiler

\begin{tabular}{cccc} 
& & Katılımcı & Yüzde \\
\cline { 3 - 4 } Cinsiyet & Kadın & 405 & $\% 37,92$ \\
& Erkek & 663 & $\% 62,08$ \\
\hline Yaş & $\mathbf{1 2 1 7}$ & 17 & $\% 1,59$ \\
& $\mathbf{1 8 - 2 4}$ & 229 & $\% 21,44$ \\
& $\mathbf{2 5 - 3 4}$ & 452 & $\% 42,32$ \\
& $\mathbf{3 5 - 4 4}$ & 293 & $\% 27,43$ \\
& $\mathbf{4 5 - 5 4}$ & 64 & $\% 5,99$ \\
& $\mathbf{5 5 - 6 4}$ & 8 & $\% 0,75$ \\
& $\mathbf{6 5 +}$ & 5 & $\% 0,47$ \\
\hline Eğitim & ilkokul & 46 & $\% 4,31$ \\
& Ortaokul & 75 & $\% 7,02$ \\
& Lise & 605 & $\% 56,6$ \\
& Ön Lisans & 178 & $\% 16,67$ \\
& Lisans & 146 & $\% 1,69$ \\
& Yüksek Lisans & 18 & $\% 100,00$ \\
\hline
\end{tabular}




\subsubsection{Katılımcıların Yaşadığı Şehir Dağııımı}

Ülkemizin 81 ilinde ikamet eden Sağır bireylerin tamamına sorulan sorulara verilen cevaplar üzerinden gerçekleştirilen anket sonuçları aşağıdaki gibidir:

İkamet ettikleri yerin hangi coğrafi bölgede yer aldığı sorusuna vermiş oldukları cevaplar incelendiğinde ise; \%4,77'sinin Karadeniz Bölgesi, \%36,98'inin Marmara Bölgesi, \%11,14'ünün Ege Bölgesi, \%28,08'inin iç Anadolu Bölgesi, \%9,83'ünün Akdeniz Bölgesi, \%4,68'sinin Doğu Anadolu Bölgesi, \%3,74'ünün Güneydoğu Anadolu Bölgesi ve $\% 0,84$ 'ünün yurtdışında ikamet ettikleri sonucuna varılmıştır.

\section{Şekil 1}

Türkiye'deki illerin katılımcı sayıları

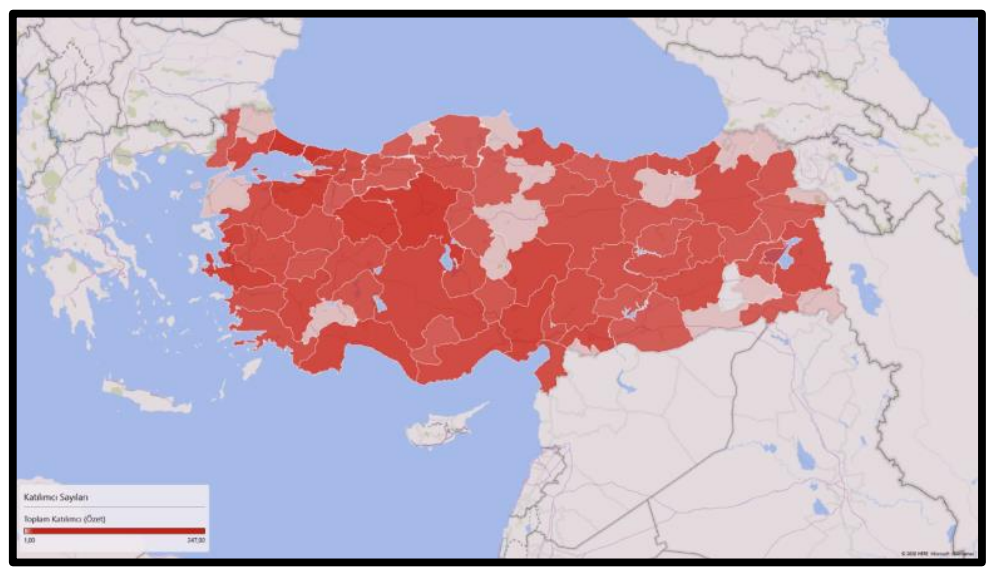

\subsubsection{Katılımcıların Yaşı, İ̧itme Kaybı ve Derecesi}

Araştırmada Tablo 2'de görülen verilere göre 1068 kişi katılımcının yaş ve işitme kaybı derecesi karşılaştırması yapılmıştır. \%56,93 oranında 608 kişi doğuştan işitme engelli, \%13,76'sı 147 kişi 1-11 ay, \%15,92'si 170 kişi 1-3 yaşında, \%6,27'si 67 kişi 4-7 yaşında ve $\% 7,12$ 'si 76 kişi 8 yaş ve üstünde, sonradan işitme kaybı olan katılımcı olduğunu tespit edilmiştir. \%56,93 oranı ile en fazla doğuştan işitme engelli grup ilk sırada yer almıştır. Verilerden görüleceği üzere, katılımcıların yarısından biraz fazlası Sağır olarak doğmuştur $(\% 56,93)$.

\section{Tablo 2}

Katılımcıların yaşı, işitme kaybı ve derecesi

\begin{tabular}{cccc} 
& İşitme kaybı & Katılımcı & Yüzde \\
\hline Yaş & Doğuştan & 608 & $\% 56,93$ \\
& $1-11$ ay & 147 & $\% 13,76$ \\
1-3 yaş & 170 & $\% 15,92$ \\
4-7 yaş & 67 & $\% 6,27$
\end{tabular}




\begin{tabular}{llcc} 
& $\mathbf{8 - 1 2}$ yaş & 16 & $\% 1,50$ \\
& $\mathbf{1 2 - 1 7}$ yaş & 5 & $\% 0,47$ \\
& $\mathbf{1 8 +}$ yaş & 55 & $\% 5,15$ \\
\hline Derece & Çok hafif derece & 78 & $\% 7,30$ \\
& Hafif derece & 4 & $\% 0,37$ \\
& Orta derece & 372 & $\% 34,83$ \\
& ileri derece & 377 & $\% 35,30$ \\
& Çok ileri derece & 237 & $\% 22,19$ \\
& Toplam & $\mathbf{1 0 6 8}$ & $\% 100,00$ \\
\hline
\end{tabular}

\subsubsection{Katılımcıların Türk İşaret Dili Kullanımı ve Yeterliliği}

İşaret dili yeterliliğine gelince, 405 (\%37,92) katılımcıların çoğu kendilerini "iji” olarak tanımlarken, $373(\% 34,93)$ ve $211(\% 19,76)$ katılımcı kendilerini sırasıyla "Çok iyi" ve "Orta" olarak tanımlamıştır.

Katılımcılardan \%47,10'u 13 yıldan fazla ve çok erken işaret dili öğrenmiştir. $\% 9,74$ ü 8-12 yıl arası olup, bunlarında işaret dilini erken öğrendiği görülmektedir. $\% 15,36$ 'sı ise, 1-3 yıl ve işaret dilini geç öğrenmiştir. Katılımcılardan 173 ü $(\% 16,2)$ işaret dili bilmemektedir. Bu veriler de işaret dili kullanımındaki eksiklikleri göstermektedir.

\section{Tablo 3}

Katılımcıların Türk işaret dili kullanımı ve yeterliliği

\begin{tabular}{clcc}
\hline \multicolumn{1}{c}{ TíD } & & Katılımcı & Yüzde \\
\hline TíD kullanımı (yıl) & $\mathbf{1}$ yıl & 85 & $\% 7,96$ \\
& $\mathbf{2 - 3}$ yıl & 79 & $\% 7,40$ \\
& $\mathbf{4 - 7}$ yıl & 124 & $\% 11,61$ \\
& $\mathbf{8 - 1 2}$ yıl & 104 & $\% 9,74$ \\
& $\mathbf{1 3 +}$ yıl & 503 & $\% 47,10$ \\
& Bilmiyorum & 173 & $\% 16,20$ \\
\hline TíD yeterliliği & Hiç & 15 & $\% 1,40$ \\
& Az & 64 & $\% 5,99$ \\
& Orta & 211 & $\% 19,76$ \\
& İyi & 405 & $\% 37,92$ \\
& Çok iyi & 373 & $\% 34,93$ \\
& Toplam & 1068 & $\% 100,00$ \\
\hline
\end{tabular}

\subsubsection{Katııımcılara iliş̧kin Çekirdek Ailedeki Sağır Durumu}

Katılımcıların sadece \%69,66'sının evde Sağır ebeveynlerinden, akrabalarından veya kardeşlerinden işaret dili öğrendikleri tespit edilmiştir. Sağır olarak doğan Sağırların yüzde beşinin Sağır ebeveynleri ve yüzde beşinin Sağır olan bir ebeveyni vardır (Kyle ve Allsop, 1982; Kyle ve Woll, 1985). 
İngiliz İşaret Dili'nde doğal akıcılık ve dilde bilgili olan, mevcut sağır çocukların yaklaşık \%90'ı işiten ailelerde doğduğundan, \%5'inde bir Sağır ebeveyn ile bir işiten ebeveyn ve sadece \%5'inde iki Sağır ebeveyn bulunmaktadır (Brien, 1992, s. 3). Bu nedenle, Sağır bireylerin sadece küçük bir kısmı doğuştan itibaren işaret diline erişebilmektedir. Geri kalanı normal edinim döneminde Türk İşaret Dili veya Türkçe bilgisi edinmemiştir. İşiten ebeveynler, işitme engelli çocuğun doğumundan önce genellikle Sağır topluluğu ile ilgili çok az temasa ve bilgiye sahiptir.

\section{Tablo 4}

\section{Katılımcılara ilişkin çekirdek ailedeki sağır durumu}

\begin{tabular}{ccc}
\hline \multicolumn{3}{c}{ Çekirdek ailedeki işitme engelli sayısı } \\
\hline Hiç & Katılımcı & Yüzde \\
\cline { 2 - 3 } $\mathbf{1}$ & 324 & $\% 30,34$ \\
$\mathbf{2}$ & 269 & $\% 25,19$ \\
$\mathbf{3}$ & 229 & $\% 21,44$ \\
$\mathbf{4}$ & 101 & $\% 9,46$ \\
$\mathbf{5}$ & 66 & $\% 6,18$ \\
Toplam & $\mathbf{7 9}$ & $\% 7,40$ \\
& $\mathbf{1 0 6 8}$ & $\% 100,00$ \\
\hline
\end{tabular}

Çekirdek ailede, kendisinden büyük olan işitme engelli olup olmadığı, var ise kaç kişi olduğu ile ilgili konuya tabloya yer verilmiştir (Tablo 5). Ailede başka işitme engelli bulunmaması halinde, işaret dili öğrenmek için yeterli girdi olamamakta, 5 büyük işitme engelli olması durumunda işaret dili öğrenme düzeyi artış göstermektedir. İşaret dili öğrenmede yardımlaşma ve dayanışmanın önemi ortaya çıkmaktadır.

\section{Tablo 5}

Çekirdek ailedeki kendisinden büyük işitme engelli sayısı

\begin{tabular}{ccc}
\hline \multicolumn{3}{c}{ Çekirdek ailedeki kendisinden büyük işitme engelli sayısı } \\
Katılımcı & Yüzde \\
\cline { 2 - 3 } Hiç & 422 & $\% 39,51$ \\
$\mathbf{1}$ & 171 & $\% 16,01$ \\
$\mathbf{2}$ & 150 & $\% 14,04$ \\
$\mathbf{3}$ & 88 & $\% 8,24$ \\
$\mathbf{4}$ & 75 & $\% 7,02$ \\
$\mathbf{5}$ & 162 & $\% 15,17$ \\
Toplam & $\mathbf{1 0 6 8}$ & $\% \mathbf{1 0 0 , 0 0}$ \\
\hline
\end{tabular}

\subsubsection{Katılımcıların İşitme Cihazı ve Gözlük Kullanımı}

İşitme cihazlarına gelince, $474(\% 44,38)$ katılımcı işitme cihazı kullanırken, $63(\% 5,9)$ katılımcı koklear implant kullanmakta ve $497(\% 46,54)$ de hiç işitme cihazı kullanmamaktır. Koklear implant kullanan 63 katılımcı varken; \%3,18'i (34 kişi) hem 
koklear implant, hem de işitme cihazı kullanmaktadır. İşitme cihazı kullanan katılımcılar altyazı çevirisinden daha fazla yararlandığı, işitme cihazı kullanmayan katılımcılar ise, genellikle çevirmenden yararlandığı düşünülmektedir.

Tablo 6

Katılımcıların işitme cihazı ve gözlük kullanımı

\begin{tabular}{lcc}
\hline & İşitme cihazı kullanımı \\
\hline & Katılımcı & Yüzde \\
\cline { 2 - 3 } Hiç kullanmıyor & 497 & $\% 46,54$ \\
İşitme cihazı & 474 & $\% 44,38$ \\
Koklear implant & 63 & $\% 5,90$ \\
Koklear implant + işitme cihazı & 34 & $\% 3,18$ \\
\hline
\end{tabular}

İşitme engelli olan katılımcılardan 757'si gözlük kullanmazken, 294 katılımcı, $\% 27,53$ 'ü gözlük kullanmaktadır.

\section{Tablo 7}

\section{Gözlük veya lens kullanımı}

\begin{tabular}{lcc}
\hline \multicolumn{3}{c}{ Gözlük veya lens kullanımı } \\
\hline & Katılımc & Yüzde \\
\cline { 2 - 3 } Kullanmıyor & 757 & $\% 70,88$ \\
Gözlük & 294 & $\% 27,53$ \\
Lens & 17 & $\% 1,59$ \\
Toplam & $\mathbf{1 0 6 8}$ & $\% \mathbf{1 0 0 , 0 0}$ \\
\hline
\end{tabular}

\subsubsection{Katılımcılara İlişkin Okuryazarlık Düzeyi}

Okuryazarlık düzeyleri ile ilgili güvenilir bir araştırma olmadığından, okuryazarlık yeterliliği tablosunda katılımcıların \%53,28'inin okuryazarlık oranlarının orta seviyeden daha düşük olduğu tespit edilmiştir.

Tablo 8

Katılımcılara ilişkin okuryazarlık düzeyi

\begin{tabular}{lcc}
\hline \multicolumn{3}{c}{ Okuryazarlık düzeyi } \\
\hline Hiç & Katılımcı & Yüzde \\
\cline { 2 - 3 } Az & 11 & $\% 1,03$ \\
Orta & 137 & $\% 12,83$ \\
İyi & 421 & $\% 39,42$ \\
Çok iyi & 347 & $\% 32,49$ \\
Toplam & 152 & $\% 14,23$ \\
\hline
\end{tabular}


Televizyon Haber Bültenlerindeki İşaret Dili Çeviri Hizmetine Yönelik Sağır Topluluğun

Tutum ve Beklentileri

\subsubsection{Katılımcılara İlişkin Sağır Topluluğa Aidiyet Durumu}

1068 katılımcıdan \%3,18'i 34 kişi hiç işitme engellilerle birlikte olmadığı, \%45,88'i 490 kişi ise hem işitme engelliler, hem de işiten ve konuşan kişilerle birlikte olduğu görülmektedir. Katılımcıların \%45,88'inin (490 kişi) aidiyet durumu çoğunluğu oluşturmaktadır.

Tablo 9

Katılımcılara ilişkin sağır topluluğa aidiyet durumu

\begin{tabular}{lcc}
\hline \multicolumn{3}{c}{ Sağır topluluğa aitlik durumu } \\
\hline Hiç & Katılımcı & Yüzde \\
\cline { 2 - 3 } Az & 34 & $\% 3,18$ \\
Orta & 206 & $\% 19,29$ \\
Çok & 490 & $\% 45,88$ \\
Çok fazla & 192 & $\% 17,98$ \\
Toplam & 146 & $\% 13,67$ \\
\hline
\end{tabular}

\subsubsection{Katılımcılara İlişkin İletişim Durumu}

Sağır katılımcıların işiten kişilerle iletişim türü sorularak ölçümleme yapılmıştır. Öncelikle katılımcılara "işiten kişilerle nasıl iletişim kurdukları" sorularak, ölçülen değerler frekans analizi ile incelenmiştir. Tablo 10'a göre katılımcıların \%28,18'i işiten kişilerle hem Türkçe konuşarak (dudak okuyarak), hem de yazı yazarak iletişim kurmaktadır. Diğer iletişim türü tercihlerine bakıldığında; hem yazı yazarak hem de Türk İşaret Dili ile iletişim kurabilen katılımcıların oranı \%20.13 olmuştur. Sadece Türk İşaret Dili ile iletişim kurabilenlerin oranı ise \%6.55'te kalmıştır.

Tablo 10

\section{Katılımcılara ilişkin iletişim durumu}

\begin{tabular}{lcc}
\hline \multicolumn{3}{c}{ İ̧̧iten kişiyle iletişim türü } \\
& Katılımcı & Yüzde \\
\cline { 2 - 3 } Sadece TiD & 70 & $\% 6,55$ \\
Sadece Türkçe (yazı) & 171 & $\% 16,01$ \\
Türkçe (konuşma, dudak okuma) + TiD & 188 & $\% 17,60$ \\
Türkçe(yazı) + Tí & 215 & $\% 20,13$ \\
Türkçe (konuşma, dudak konuşma) & 123 & $\% 11,52$ \\
Türkçe (konuşma dudak okuma) + Türkçe (yazı) & 301 & $\% 28,18$ \\
\hline
\end{tabular}

Katılımcıların, \%17,23'ü, 84 kişi Türkçeyi iletişim dili olarak tercih ederken, \%24,06'sı 257 kişi, Türk İşaret Dilini tercih ettiği görülmekte, \%56,27'si, 601 kişi ise hem Türkçe, hem de Türk İşaret Dilini tercih ettiği için ve çoğunluğu oluşturduğu ölçülmüştür. 
Tablo 11

Katılımcılara ilişkin dil tercihi

\begin{tabular}{lcc}
\hline \multicolumn{1}{c}{ Dil tercihi } \\
\hline Türkçe & 184 & $\% 17,23$ \\
Tí & 257 & $\% 24,06$ \\
Türkçe + Tí & 601 & $\% 56,27$ \\
Farklı bir dil (İngilizce, uluslararası işaret vb.) & 26 & $\% 2,43$ \\
Toplam & $\mathbf{1 0 6 8}$ & $\% 100,00$ \\
\hline
\end{tabular}

\subsection{Sağır Katılımcıların Televizyon Tercihleri}

\subsubsection{Katılımcıların Günlük Televizyon İzleme Oranı}

Katılımcıların günlük ortalama televizyon izleme saatini ölçmek için hazırlanan soru grubunda, "bir günde televizyon izleme saati" sorulmuştur. Alınan cevaplar doğrultusunda yapılan frekans analizine göre (Tablo 12); katılımcıların \%44,94'ü günde 2-3 saat aralığında televizyon izlediğini belirtmiştir. Televizyonu hiç izlemeyenlerin oranı ise $\% 2,72$ olarak görülmektedir.

Genel olarak Sağır bireyler günde 1 saatin üzerinde televizyon izlemektedir. Bu nedenle, Sağır bireylerin her türlü konuyu anlayabilmeleri için, televizyonlarda daha çok çevirmene ve altyazı çevirisine yer verilmesine ihtiyaç duyulmaktadır.

Tablo 12

Katılımcıların günlük televizyon izleme oranı

\begin{tabular}{lcc}
\hline \multicolumn{3}{c}{ Günlük televizyon izleme oranı } \\
\hline Hiç & Katılımcı & Yüzde \\
\cline { 2 - 3 } 0-1 saat & 29 & $\% 2,72$ \\
$\mathbf{2 - 3}$ saat & 250 & $\% 23,41$ \\
4-7 saat & 480 & $\% 44,94$ \\
8-12 saat & 210 & $\% 19,66$ \\
13+ & 53 & $\% 4,96$ \\
Toplam & 46 & $\% 4,31$ \\
\hline
\end{tabular}

\subsubsection{Katılımcılara Göze İzlenen Televizyon İzlenen Programlar}

Tercih edilen ve en yüksek önceliğe sahip program türleri Haber, Film, Dizi ve Spordur. (Tablo 13.) Açık arayla en büyük grup $(\% 89,42)$ Haber programlarına izlemektedir. Beklendiği gibi görüntülenen belirli program türleri açısından Haberler, en popüler olandır. Yaşı insanların her gün izlemesi daha olasıdır (\%83). Her Sağır yaşlı bireyin teknoloji ile ilgileri olmadığı (Yeterince sosyal medya kullanamadıkları) için televizyon onlar için büyük ihtiyaçtır. 
Televizyon Haber Bültenlerindeki İşaret Dili Çeviri Hizmetine Yönelik Sağır Topluluğun Tutum ve Beklentileri

Tablo 13

Katılımcılara ilişkin televizyon izlenen programlar(sıralama)

\begin{tabular}{cccc}
\hline \multicolumn{4}{c}{ Katılımcılara ilişkin televizyon izlenen programlar } \\
\hline $\mathbf{1}$ & Programlar & Katılımcı & Yüzde \\
\cline { 2 - 4 } $\mathbf{2}$ & Haber & 955 & $\% 89,42$ \\
$\mathbf{3}$ & Sinema/film & 818 & $\% 76,59$ \\
$\mathbf{4}$ & Dizi & 689 & $\% 64,51$ \\
$\mathbf{5}$ & Spor & 586 & $\% 54,87$ \\
$\mathbf{6}$ & Yarışma & 517 & $\% 48,41$ \\
$\mathbf{7}$ & Belgesel & 474 & $\% 44,38$ \\
$\mathbf{8}$ & Kültür & 386 & $\% 36,14$ \\
$\mathbf{9}$ & Çizgi film & 342 & $\% 32,02$ \\
$\mathbf{1 0}$ & Magazin-eğlence & 294 & $\% 27,53$ \\
$\mathbf{1 1}$ & Sanat & 278 & $\% 26,03$ \\
$\mathbf{1 2}$ & Açık oturum-tartışma & 218 & $\% 20,41$ \\
& Müzik & 178 & $\% 16,67$ \\
\hline
\end{tabular}

Anketin ikinci bölümü televizyon tercihleri ile ilgilidir. Sonuçlar; katılımcıların $\% 89,42$ 'sinin haber bültenlerini izlemekte olduğunu, çoğunlukla ise sinema/film $(\% 76,59)$, dizi $(\% 64,51)$ ve spor $(\% 54,87)$ programlarını izlediklerini göstermektedir. Diğer programlar ise Şekil 2'de gösterilmektedir.

\section{Şekil 2}

İlenen Programları

\section{IZLENEN PROGRAMLAR (KATILIMCI SAYISI: 1068)}

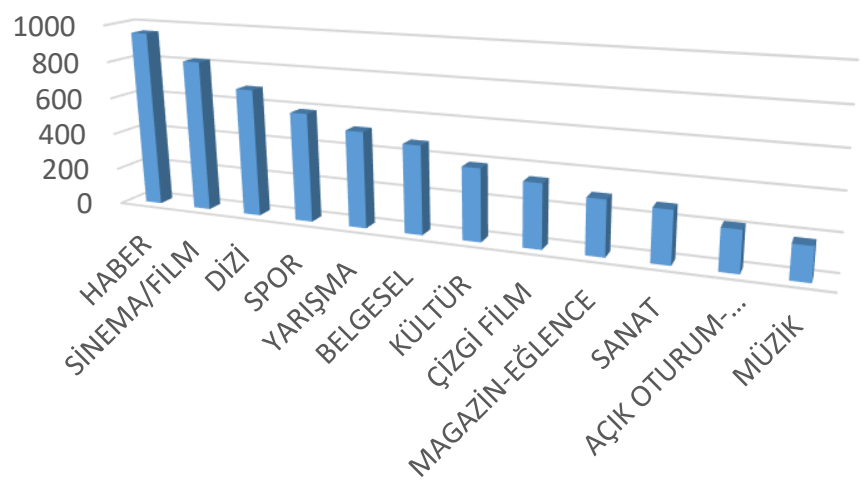




\subsubsection{Katılımcılara İlişkin Günlük Ortalama Televizyondaki Haber Programlarını Takip Etme Oranı}

Tablo 14'ten anlaşılacağı üzere anket araştırması sorusunu 1068 katılımcı cevaplamıştır. Bu katılımcılara ilişkin günlük ortalama televizyondaki haber programlarını takip etme oranını ise şöyle sıralamak mümkün: 67 katılımcı \%6,27 oranla haber programlarını "hiç" takip etmemekteyken, 82 katılımcı \%7,68 oranda "nadiren" takip etmekte, 583 katılımcı \%54,59 oranda "bazen" takip etmekte, 116 katılımcı \%10,86 oranda "sıklıkla", 220 katılımcı ise \%20,6 oranda "sürekli" takip etmektedir.

Tablo 14

Katılımcılara ilişkin günlük ortalama televizyondaki Haber programlarını takip etme oranı

\begin{tabular}{ccc}
\hline \multicolumn{3}{c}{ Günlük ortalama televizyondaki haber programlarını takip etme oranı } \\
\cline { 2 - 3 } Hiç & Katılımcı & Yüzde \\
Nadiren & 67 & $\% 6,27$ \\
Bazen & 82 & $\% 7,68$ \\
Sıklıkla & 583 & $\% 54,59$ \\
Sürekli & 116 & $\% 10,86$ \\
Toplam & 220 & $\% 20,60$ \\
& $\mathbf{1 0 6 8}$ & $\% \mathbf{1 0 0 , 0 0}$ \\
\hline
\end{tabular}

\subsubsection{Katılımcıların televizyondaki haber programlarını takip ettiği zamanları (sıralama)}

Sağır katılımcılara televizyon haber programlarını izleme alışkanlıkları sorulduğunda, \%89,33'ü hafta içi akşamları izledikleri belirtilmektedir. Sağır katılımcıların çoğunlukla akşam saatlerinde (hafta içi \%89,33 / hafta sonu \%63,95) TV izleme eğiliminde olduğunu göstermektedir. Bu ankete katılan Sağırların yüzde 63,12'si hafta sonları çoğunlukla akşam saatlerinde TV izledikleri görülmektedir.

\section{Tablo 15}

Katılımcıların televizyondaki haber programlarını takip ettiği zamanları (sıralama)

Katılımcıların televizyondaki haber programlarını takip ettiği zamanları (sıralama)

\begin{tabular}{llcc}
\hline & \multicolumn{1}{c}{ Programlar } & Katılımcı & Yüzde \\
\cline { 2 - 4 } $\mathbf{1}$ & Hafta içi akşam & 954 & $\% 89,33$ \\
$\mathbf{2}$ & Hafta sonu akşam & 683 & $\% 63,95$ \\
$\mathbf{3}$ & Hafta sonu öğle & 220 & $\% 20,60$ \\
$\mathbf{4}$ & Hafta içi öğle & 201 & $\% 18,82$ \\
$\mathbf{5}$ & Hafta içi sabah & 181 & $\% 16,95$ \\
$\mathbf{6}$ & Hafta sonu sabah & 179 & $\% 16,76$ \\
\hline
\end{tabular}


Televizyon Haber Bültenlerindeki İşaret Dili Çeviri Hizmetine Yönelik Sağır Topluluğun

Tutum ve Beklentileri

\subsubsection{Katılımcıların Evindeki Televizyon Kullanımı ve Türleri}

Katılımcıların \%6,55'inin (70 kişi) evinde tüplü televizyon bulunduğu görülürken, \%62,55'inin Smart TV bulunduğu tespit edilmiştir.

\section{Tablo 16}

Katılımcıların evindeki televizyon kullanımı ve türleri

\begin{tabular}{lcc}
\hline & Katılımcıların evindeki televizyonun monitör türü \\
\hline & Katılımcı & Yüzde \\
\cline { 2 - 3 } Tüplü & 70 & $\% 6,55$ \\
Lcd tv & 273 & $\% 25,56$ \\
Led tv & 17 & $\% 1,59$ \\
Smart tv & 668 & $\% 62,55$ \\
Oled tv & 40 & $\% 3,75$ \\
\hline
\end{tabular}

Katılımcılardan \%5,06'sının (54 kişi) evinde 22"- 26" ölçülerinde televizyon kullanırken, \%25,28'inin (270 kişi) 38"- 42" ebadında televizyon kullandığı görülmektedir. Evinde 42" ve daha küçük ekran televizyonu bulunan katılımcı \%49,34'ünün (522 kişi) ekrandaki çevirmen görüntüsünün küçük ve yetersiz olduğunu düşünmektedir.

\section{Tablo 17}

Evinde kullandığı televizyonun ekran ölçüsü

\begin{tabular}{lcc}
\hline & Evinde kullandığı televizyonun ekran ölçüsü & \\
\hline & Katılımcı & Yüzde \\
\cline { 2 - 3 } $\mathbf{2 2 " - 2 6 " ~}$ & 54 & $\% 5,06$ \\
$\mathbf{2 7 " - 3 2 "}$ & 81 & $\% 7,58$ \\
$\mathbf{3 3 " - 3 7 "}$ & 122 & $\% 11,42$ \\
$\mathbf{3 8 " - 4 2 "}$ & 270 & $\% 25,28$ \\
$\mathbf{4 3 " - 4 6 "}$ & 263 & $\% 24,63$ \\
$\mathbf{4 7 " - 5 2 "}$ & 185 & $\% 17,32$ \\
$\mathbf{5 3 " +}$ & 93 & $\% 8,71$ \\
\hline
\end{tabular}

Katılımcıların \%29,95'i (320 kişi) sayısal yayın yapan dijital platformları (Digitürk, Dsmart, Tivibu, Teledünya, Turkcell TV) kullanırken, \%66,02'si (705 kişi) analog yayın yapan normal antenli kablo TV ve uydu antenli televizyon kullandığı görülmüştür. Sağır bireylerin olduğu \%66,02'si gibi çoğunluğu oluşturan kesimin ekonomik durumunun yeterli olmadığı ve dijital platformlardan yararlanan Sağır bireylerin olanaklarına sahip olmaması nedeniyle teknolojik yeniliklerden mahrum kaldığı anlaşılmaktadır. 
Tablo 18

Evindeki televizyonun uydu teknolojisi veya dijital yayını kullanımı

Evindeki televizyonun uydu teknolojisi veya dijital yayını kullanımı

\begin{tabular}{lcc}
\hline & Katılımcı & Yüzde \\
\cline { 2 - 3 } Normal kablo (anten) & 189 & $\% 17,70$ \\
Uydu & 412 & $\% 38,58$ \\
Digitürk & 119 & $\% 11,14$ \\
Dsmart & 53 & $\% 4,96$ \\
Tivibu & 74 & $\% 6,93$ \\
Kablo tv & 104 & $\% 9,74$ \\
Teledünya & 13 & $\% 1,22$ \\
Turkcell tv+ & 61 & $\% 5,71$ \\
İnternet (iptv..vb) & 43 & $\% 4,03$ \\
Toplam & $\mathbf{1 0 6 8}$ & $\% \mathbf{1 0 0 , 0 0}$ \\
\hline
\end{tabular}

\subsection{Sağır Katılımcılarının Haber Çevirisine İlişkin Teknik Beklentileri}

\subsubsection{Katılımcılara ilişkin Çevirmenin Ekranda Kapladığı Alanları}

Katılımcıların \%49,16’sı (525 kişi) ekranın 1/3'ünün sağır çevirmenin kaplamasını tercih ederken, \%1,31'i (14 kişi) ekranın 1/12'sini kaplamasını istediği görülmektedir. Genel ortalamanın $1 / 3$ oranı olduğu ölçülmüştür.

Tablo 19

Katılımcılara ilişkin çevirmenin ekranda kapladığı alanları

\begin{tabular}{lccc}
\hline & \multicolumn{2}{c}{ Sağır katılımcılarının istediği çevirmenin ekranda kapladığı alan } \\
\hline & Alan & Katılımcı & Yüzde \\
\hline $\mathbf{1}$ & $\mathbf{1 / 3}$ & 525 & $\% 49,16$ \\
$\mathbf{2}$ & $\mathbf{1 / 4}$ & 438 & $\% 41,01$ \\
$\mathbf{3}$ & $\mathbf{1 / 2}$ & 419 & $\% 39,23$ \\
$\mathbf{4}$ & $\mathbf{1 / 8}$ & 63 & $\% 5,90$ \\
$\mathbf{5}$ & $\mathbf{1 / 1 2}$ & 14 & $\% 1,31$ \\
& Genel ortalama & $\mathbf{1 / 3}$ & \\
\hline
\end{tabular}

\subsubsection{Katılımcılara iliş̧in Çevirmenin Arka Planı}

Katılımcıların \%55,15'inin (589 kişi) saydam (boş) arka plan tercih etmektedir. Saydam arka planda Sağır topluluğun çevirmenin el hareketlerini ve mimiklerini daha iyi anladığı ve optimum düzeyde yararlandığı görülmektedir. 
Tablo 20

Katılımcılara ilişkin çevirmenin arka planı

\begin{tabular}{lccc}
\hline & \multicolumn{3}{c}{ Sağır katılımcılarının istediği çevirmenin arka planı (sıralama) } \\
\hline & Renk & Katılımcı & Yüzde \\
\cline { 2 - 4 } $\mathbf{1}$ & Saydam (boş) & 589 & $\% 55,15$ \\
$\mathbf{2}$ & Beyaz & 338 & $\% 31,65$ \\
$\mathbf{3}$ & Mavi & 195 & $\% 18,26$ \\
$\mathbf{4}$ & Gri & 140 & $\% 13,11$ \\
$\mathbf{5}$ & Siyah & 26 & $\% 2,43$ \\
$\mathbf{6}$ & Diğer & 22 & $\% 2,02$ \\
$\mathbf{7}$ & Fark etmez & 17 & $\% 1,15$ \\
\hline
\end{tabular}

\subsubsection{Katılımcıların, Çevirmenin Kıyafetine ilişskin İsteği}

Katılımcıların \%60,39'u (645 kişi) çevirmenin kıyafeti konusunda görüş beyan etmezken \%18,07'si (193 kişi) düz tişört tercih ettiği görülmektedir. Renkli, desenli tişört vb. kıyafet dikkat dağınıklığına sebep olabileceği dikkate alındığında düz tişört tercihinin daha talep edilen olduğu düşünülebilir.

Tablo 21

Katılımcıların, çevirmenin kıyafetine ilişkin isteği

\begin{tabular}{llcc}
\hline \multicolumn{3}{c}{ Çevirmenin kıyafet türünü giyimi } \\
\hline & & Katılımcı & Yüzde \\
\cline { 3 - 4 } $\mathbf{1}$ & Klasik kıyafet (takım elbise vb.) & 230 & $\% 21,54$ \\
$\mathbf{2}$ & Günlük kıyafet (düz tişört vb.) & 193 & $\% 18,07$ \\
$\mathbf{3}$ & Fark etmez & 645 & $\% 60,39$ \\
& Toplam & $\mathbf{1 0 6 8}$ & $\% \mathbf{1 0 0 , 0 0}$ \\
\hline
\end{tabular}

\subsubsection{Katılımcıların, Çevirmenin Kıyafet Rengi Talebi}

Katılımcıların \%68,45'i (731 kişi) çevirmenin kıyafetinin siyah renk olmasını tercih ettiği ölçümlenmiştir. Diğer kıyafet renkleri tercih edenlerin oranı düşük seviyede kaldığı görülmektedir. Avrupa ülkelerinde de yapılan araştırmalarda çevirmenin kıyafetinin siyah renk olmasının kabul gördüğü düşünülmektedir. 
Tablo 22

Katılımcıların, çevirmenin kıyafet rengi talebi

\begin{tabular}{lccc}
\hline \multicolumn{4}{c}{ Sağır katılımcılarının istediği çevirmenin kıyafet renkleri (sıralama) } \\
\hline & Renk & Katılımcı & Yüzde \\
\hline $\mathbf{1}$ & Siyah & 731 & $\% 68,45$ \\
$\mathbf{2}$ & Gri & 196 & $\% 18,35$ \\
$\mathbf{3}$ & Kırmızı & 168 & $\% 15,73$ \\
$\mathbf{4}$ & Mavi & 164 & $\% 15,36$ \\
$\mathbf{5}$ & Diğer & 20 & $\% 1,87$ \\
$\mathbf{6}$ & Fark etmez & 93 & $\% 8,70$ \\
\hline
\end{tabular}

\subsubsection{Katılımcılara ilişkin çevirmenin takı, saat vb. Kullanımı}

Katılımcıların \%47,00'si (502 kişi) görüş beyan etmemekte iken, \%22,94'ü (245 kişi) çevirmenin kesinlikle takı takmaması gerektiğini belirtmektedir. Sağır topluluğun dikkatimin dağılmaması ve çevirmenden azami ölçüde yararlanabilmesi için saat, kolye, yüzük, küpe vb. takıların kullanılmaması düşünülmektedir.

\section{Tablo 23}

Katılımcılara ilişkin çevirmenin takı, saat vb. kullanımı

\begin{tabular}{lcc}
\hline \multicolumn{3}{c}{ Çevirmenin takı, saat vb. kullanımı } \\
\hline & Katılımcı & Yüzde \\
\cline { 2 - 3 } Kesinlikle olmamalı & 245 & $\% 22,94$ \\
Olmamalı & 158 & $\% 14,79$ \\
Bilmiyorum & 72 & $\% 6,74$ \\
Olabilir & 91 & $\% 8,52$ \\
Fark etmez & 502 & $\% 47,00$ \\
Toplam & 1068 & $\% 100,00$ \\
\hline
\end{tabular}

\subsubsection{Katılımcılara Göre, Çevirmenin Duruş Biçimi}

Katılımcıların \%26,31'i (281 kişi) çevirmenin ayakta durmasını tercih edip, \%58,43'ü (624 kişi) görüş beyan etmemiştir. Çevirmenin el, kol ve vücut hareketlerinin anlaşılır olması ve çevirmenin rahat hareket etmesi için ayakta durması görüşü düşünülmektedir. 
Televizyon Haber Bültenlerindeki İşaret Dili Çeviri Hizmetine Yönelik Sağır Topluluğun Tutum ve Beklentileri

Tablo 24

Katılımcılara göre, çevirmenin duruş biçimi

\begin{tabular}{lcc}
\hline & \multicolumn{2}{c}{ Çevirmenin duruş biçimi } \\
\hline & Katılımcı & Yüzde \\
\cline { 2 - 3 } Ayakta durmalı & 281 & $\% 26,31$ \\
Oturmalı & 163 & $\% 15,26$ \\
Fark etmez & 624 & $\% 58,43$ \\
Toplam & $\mathbf{1 0 6 8}$ & $\% \mathbf{1 0 0 , 0 0}$ \\
\hline
\end{tabular}

\subsubsection{Katılımcılara ilişkin Yardımcı/Rehber Çevirmen Olarak Sağır Çevirmen}

Sağır topluluğun dış dünyadan haberdar olması ve televizyon haber bültenleri vb. yayınları öğrenmesi için Türk İşaret Diline yetkin olan, eğitimli, donanımlı tercümanlara ihtiyaçları vardır. Sağır topluluk kültürünü bilen, o toplum içinden gelen Sağır çevirmen sağır ve işitme engelliler için oldukça yararlıdır.

İdeal olarak, bir Sağır danışmanı / monitörü, tercihen yayın kuruluşu veya çevirmenleri sağlayan kuruluş tarafından atanan hazırlık ve çeviri sonrası geri bildirime yardımcı olmalıdır (bkz. Antonsen, 2006; Leeson, 2005). Bu desteğin başarısız olması halinde, çevirmenler bir sağır arkadaşının yardımına başvurmalıdır. Aynı zamanda, sağlıklı çeviri için yapıldığı gibi bir terminoloji işaret bankası oluşturulmasına ihtiyaç vardır (Bontempo, K., \& Napier, J. 2011). Katılımcılardan \%45,88'inin (490 kişi) Sağır çevirmen tercihinde bulunduğu görülmüştür. Sağır topluluğa yönelik yapılan çeviri de çevirmenin çeviri yapamadığı veya eksik çevirilerde Sağır çevirmenlerden yardım alınabilecek ve yapılan çeviri kaliteli, anlaşılır olabilecektir.

\section{Tablo 25}

Katılımcılara ilişkin yardımcı/rehber çevirmen olarak sağır çevirmen

\begin{tabular}{lcc}
\hline \multicolumn{2}{c}{ Yardımcı/rehber çevirmen olarak sağır çevirmen } \\
\hline & Katılımcı & Yüzde \\
\cline { 2 - 3 } Evet, sağır çevirmen bulunmalı & 490 & $\% 45,88$ \\
Fark etmez & 207 & $\% 19,38$ \\
Hayır, gerek yok & 371 & $\% 34,74$ \\
Toplam & 1068 & $\% 100,00$ \\
\hline
\end{tabular}

\subsubsection{Katılımcılara İlişkin Televizyondaki Dil Tercihi}

Katılımcılar ekranda sadece çevirmen, çevirmen ve altyazı çevirisi, sadece altyazı çevirisi ve sadece spiker olması tercihini, çevirmen ve altyazı çevirisi yönünde kullandığı, \%81,74 oranla (873 kişi) olduğu görülmektedir. Büyük çoğunluğu oluşturan Sağır katılımcıların, 
çevirmeninin yetersizliği veya eksik çeviri vb. nedenlerle altyazı çevirisinin de olmasını tercih ettikleri ölçümlenmiştir.

Sadece çevirmen tercihinde bulunan \%11,05 oranında (118 kişi) okuma yazmayı bilmediği veya az bilmesi sebebiyle olabileceği gibi, sadece altyazı çevirisin tercih eden \%6,74 oranla, 72 kişi ise Türk İşaret Dili bilmediği için bu şekilde tercih kullandığı düşünülmektedir.

\section{Tablo 26}

Katılımcılara ilişkin televizyondaki dil tercihi

\begin{tabular}{lcc}
\hline \multicolumn{3}{c}{ Televizyondaki dil tercihi } \\
\hline Sadıce çevirmen & Katımc & Yüzde \\
\hline Çevirmen ve altyazı & 118 & $\% 11,05$ \\
Sadece altyazı & 873 & $\% 81,74$ \\
Sadece spiker & 72 & $\% 6,74$ \\
Toplam & 5 & $\% 0,47$ \\
\end{tabular}

\subsubsection{Katılımcılara İlişkin Televizyondaki Odaklanma Sorunu}

Katılımcılardan \%45,79’u (489 kişi) odaklanma sorunu yaşamadığını belirtirken, yaklaşık eşit oranda \%44,76'sı (478 kişi) odaklanma sorunu yaşadığını ifade ettiği ölçümlenmiştir. Odaklama sorununun, çevirmenin arzulanan şekilde çeviri yapamadığından olabileceği gibi ekran alanının darlığından çevirmenin yeterli şekilde görememesinden kaynaklandığı düşünülmektedir.

Tablo 27

Katılımcılara ilişkin televizyondaki odaklanma sorunu

\begin{tabular}{lcc}
\hline \multicolumn{3}{c}{ Haber programı izlerken işaret dili çevirmeni ile ekrandaki görsel arasında } \\
odaklanma problemi
\end{tabular}

\subsubsection{Katılımcılara İlişkin Haber Programlarında Sağır Spiker Görme İstemi}

Sağır katılımcıların yüzde 54,03'ü (577 kişi) bir Sağır spikerin televizyonda kabul edilebilir olduğunu ifade ederken, sadece \%10,11'i (108 kişi) bir sağır spikeri görmek istemediğini belirlemiştir. 
Televizyon Haber Bültenlerindeki İşaret Dili Çeviri Hizmetine Yönelik Sağır Topluluğun Tutum ve Beklentileri

Tablo 28

Katılımcılara ilişkin haber programlarında sağır spiker görme istemi

\begin{tabular}{lcc}
\hline & Haber programlarında sağır spiker görme istemi & \\
\cline { 2 - 3 } Evet & Katılımcı & Yüzde \\
\cline { 2 - 3 } Hayır & 577 & $\% 54,03$ \\
Bilmiyorum & 108 & $\% 10,11$ \\
Toplam & 383 & $\% 35,86$ \\
\hline
\end{tabular}

\subsubsection{Katılımcılara İlişkin Sağırlara Özel Ayrı Yeni Bir Kanal İstemi}

Sağırlara özel ayrı kanal istemi ile ilgili, katılımcıların, \%84,27'si (900 kişi) büyük çoğunlukla ayrı kanal talep ettiği ölçümlenmiştir. Ayrı bir kanal isteminde bulunmayan sayısı 63 kişi olup \%5,9 oran ile çok küçük bir azınlık olduğu anlaşılmaktadır.

Tablo 29

Katılımcılara ilişkin sağırlara özel ayrı yeni bir kanal istemi

\begin{tabular}{lcc}
\hline \multicolumn{3}{c}{ Sağırlara özel ayrı yeni bir kanal istemi } \\
\hline & Katılımcı & Yüzde \\
\cline { 2 - 3 } Evet & 900 & $\% 84,27$ \\
Hayır & 63 & $\% 5,90$ \\
Bilmiyorum & 105 & $\% 9,83$ \\
Toplam & $\mathbf{1 0 6 8}$ & $\mathbf{1 0 0 , 0 0}$ \\
\hline
\end{tabular}

\subsection{Sağır Katılımcılarının Haber Çevirisine i̇lişkin İçeriksel Beklentiler}

\subsubsection{Katılımcılara iliş̧kin TiD Çevirmenin Haber Bülteni Öncesinde Haber Metinlerini İnceleyerek Çeviriye Hazırıı Yapması Hakkındaki Görüşü}

Katılımcılar, TiD çevirmeninin, haber bülteni öncesinde haber metinlerini incelemesi ve çeviri için hazırlık yapması konusundaki ilgisi oldukça yüksek oranda olması gerektiğini düşünmektedirler. "Kesinlikle katılıyorum" ve "Katılıyorum" seçeneğini tercih edenlerin oranı \%59,83, yani 639 kişi tarafından Türk İşaret Dili çevirmeninin çeviri öncesi hazırlık yapmasının gerekli olduğu ölçümlenmiştir.

Yeniden yapılandırma, çevirmen tarafından önceden ön hazırlık yapılmasını gerektirir. Bunun içerdiği şey "en az çaba yasası" (Gile, 1995), işaret dili çevirisi mesajların hedef kitlenin dilsel ve kültürel normlarına göre ayarlanması gerektiğine dair basit bir tanımdır. Haber çevirmeninin, büyük ölçüde eşzamanlı çeviri modeli haline gelen simültane çeviriden farklı olduğu vurgulanmalıdır. Konferans çevirmenleri, tartışılan konu ve ilgili terminoloji hakkında bilgi sahibi olan deliller için çeviri yaparken, haber çevirinin aynı bilgi kaynağını paylaşmayan daha geniş bir kitleyle tutarlı olması gerekmektedir. (bkz. Hogg, 2011). 
Türkçede bazı kelime ve terimlerin TiD’de karşılığı olmayabilmektedir. Örneğin, 'Pandemi', 'Korner' vb. Çevirmenin sağlıklı çeviri yapabilmesi ve çevirinin erek kitleye azami faydalı olabilmesi için Sağır çevirmenden veya Sağır bireylerden yardım alması gerekmektedir.

Tablo 30

Katılımcılara ilişkin TiD çevirmeninin haber bülteni öncesinde haber metinlerini inceleyerek çeviriye hazırlık yapması hakkındaki görüşü

\begin{tabular}{llcc}
\hline \multicolumn{4}{c}{ TíD çevirmeninin haber bülteni öncesinde haber metinlerini inceleyerek çeviriye } \\
hazırlık yapması hakkındaki görüşü
\end{tabular}

3.4.2 Katılımcılara İlişkin TiD Çevirmeninin Farklı Alanla İlgili Yeterli Bilgi Donanımına Sahip Olması Hakkındaki Görüşü

Katılımcıların \%42,88'i (458 kişi) "Kesinlikle katılıyorum" seçeneğini tercih ettiği, \%38,20'si (408 kişi) “katılıyorum" şekilde tercih kullanmıştır. İki seçenek toplamı alındığında, \%81,08'i (866 kişi) TiD çevirmeninin bilgi birikimine sahip olmasını istediği ölçümlenmiştir. TiD çevirmeninin çeviri yapacağı konu hakkında yeterli bilgiye sahip olması, azami ölçüde kaynak araştırması, hedef dilin cümle yapısına hâkim olması, ulusal ve uluslararası basını takip etmesi, bilgi birikimini artırması kendi mesleğinde başarısını artıracağı gibi Sağır topluluğa da yaptığı çevirilerde daha faydalı olacağı düşünülmektedir.

Tablo 31

Katılımcılara ilişkin TiD çevirmeninin farklı alanla ilgili yeterli bilgi donanımına sahip olması hakkındaki görüşü

\begin{tabular}{|c|c|c|c|}
\hline \multicolumn{4}{|c|}{$\begin{array}{l}\text { TiD çevirmeninin farklı alanla ilgili yeterli bilgi donanımına sahip olması hakkındak } \\
\text { görüşü }\end{array}$} \\
\hline & & Katılımcı & Yüzde \\
\hline 1 & Kesinlikle katılıyorum & 458 & $\% 42,88$ \\
\hline 2 & Katılıyorum & 408 & $\% 38,20$ \\
\hline 3 & Kararsızım & 123 & $\% 11,52$ \\
\hline 4 & Katılmıyorum & 57 & $\% 5,34$ \\
\hline \multirow[t]{2}{*}{5} & Kesinlikle katılmıyorum & 22 & $\% 2,06$ \\
\hline & Toplam & 1068 & $\% 100,00$ \\
\hline
\end{tabular}




\subsubsection{Katılımcılara iliş̧kin Televizyonlarda Görev Alan İ̧aret Dili Çevirmeninin Parmak Abecesini Kullanması Gereken Dereceler}

Katılımcıların \%10,11'i (108 kişi) Türk İşaret Dili çevirmeninin parmak abecesini hiç kullanmaması gerektiğini belirtirken, \%41,48'i (443 kişi) az kullanılmasını tercih ettiği, toplamda, \%51,59'u (551 kişi) parmak abecesinin az kullanılmasının daha faydalı olacağını tercih etmekte olduğu ölçümlenmiştir.

Televizyonda görev yapan çevirmenin genellikle ekran görüntüsünün küçük olması, erek kitlenin parmak abecesini okuması ve anlamasını zorlaştırmakta, oysa bazı kelimelerin isimlerini parmak işaretleri ile sembol olarak göstermesi hem anlaşılabilir olurken hem de zaman tasarrufu sağlayacağı düşünülmektedir.

Tablo 32

Katılımcılara ilişkin televizyonlarda görev alan işaret dili çevirmeninin parmak abecesini kullanmasını gereken dereceleri

\begin{tabular}{llcc}
\hline \multicolumn{4}{c}{ Televizyonlarda görev alan işaret dili çevirmeninin parmak abecesini kullanması } \\
gereken dereceler
\end{tabular}

\subsubsection{Katılımcılara iliş̧kin Televizyonlarda Görev Alan işaret Dili Çevirmeninin Sağır Kültürü Ilgili Yeterli Bilgi Donanımına Sahip Olması}

Televizyonlarda görevli işaret dili çevirmeninin Sağır kültürü hakkında bilgi birikimine sahip olması seçeneğinde, katılımcıların \%47,10’u (503 kişi) "Kesinlikle" desteklerken, $\% 34,83$ 'ü (372 kişi) desteklediği yönünde tercih kullanmaktadır. Diğer bir ifade ile $\% 81,93$ 'ü (875 kişi) çevirmenin Sağır kültürünü çok iyi bilmesi gerektiği görüşünde oldukları ölçümlenmiştir.

Sağır kültürünün iyi bilinmesi, Türk İ̧̧aret Dili çevirmeninin başarılı olması bakımından ve hedef kitleye yaptığı çevirinin istenildiği seviyede olmasını da sağlayacaktır. Sağır anne ve baba ile büyüyen işiten bir birey (CODA), Sağır kültürü içinde yetiştiği için bu kültürü çok iyi bilecektir ve Sağır çevirmeni görevini daha verimli yapacağı düşünülmektedir. 
Tablo 33

Katılımcılara ilişkin televizyonlarda görev alan işaret dili çevirmeninin sağır kültürü ilgili yeterli bilgi donanımına sahip olması

Televizyonlarda görev alan işaret dili çevirmeninin sağır kültürü ilgili yeterli bilgi donanımına sahip olması

\begin{tabular}{llcc}
\hline & & Katılımcı & Yüzde \\
\cline { 3 - 4 } $\mathbf{1}$ & Kesinlikle katılıyorum & 503 & $\% 47,10$ \\
$\mathbf{2}$ & Katılıyorum & 372 & $\% 34,83$ \\
$\mathbf{3}$ & Kararsızım & 104 & $\% 9,74$ \\
$\mathbf{4}$ & Katılmıyorum & 45 & $\% 4,21$ \\
$\mathbf{5}$ & Kesinlikle katılmıyorum & 44 & $\% 4,12$ \\
& Toplam & $\mathbf{1 0 6 8}$ & $\% \mathbf{1 0 0 , 0 0}$ \\
\hline
\end{tabular}

3.4.5 Sağır Katılımcılarının Akşam Haber Bülteninde En Çok Beğendiği Televizyon Kanalının Ana Haber Bülteninde Görev Yapan Çevirmenin Çevirisi Hakkındaki Görüşleri

Katılımcılara İşaret Dili çevirisini en beğendiği televizyon analizini yaparken, katılımcı sayısı, yetkinlik (başarı), akıcılık (durma yok), çeviri hızı (gecikme süresi), rahatlık (işaret rahat), bilgi donanımı (sağlık, spor vb.) anlaşılabilirlik (tam anlamak), sözlük seçimi (sözcük uygun çevirisi), TiD dilbilgisi yeterliliği, yüz ifadesi, vücut dili, işaret alanı kullanımı (sabit değil), duygu durum (örn. Mutlu, kızgın vb.), sağırlara uygunluğu (Sağır kültürü), parmak abecesi, Türkçe düşünmemesi (Sadece TiD) ve hatayı düzeltme ile 15 seçenek sunulmuş ve Türk İ̧aret Dili çevirisi yapan toplam beş TV kanalı içinde beğeni tercihleri puan sıralamasına tabi tutularak analiz yapılmıştır.

"İşaret dili çevirisinde en çok beğendiğiniz televizyon kanalı hangisidir?" sorusunu, 1069 kişiden 635'i anketi cevaplamış, kalan 434'ü cevap vermek istememiştir. Cevaplayan 635 kişiden, 281'i tutarsız cevaplar verdikleri için geçersiz sayılmıştır. Geçerli cevap veren 354 kişinin verdiği cevap üzerinden anket sonucuna örneklem ile ulaşılmıştır.

354 katılımcının seçenek tercihleri puanlama sıralamasına göre TV kanallarının kalite sıralaması, beşli puan sistemine uygun olarak en fazla puan alan TV kanalı dereceleme yapılmıştır (Tablo 34). Buna göre birinci sırada 3. Kanalın 4,10 puan ortalaması ile birinci, 4,03 puan ile 2.kanal, üçüncü sırada 1.kanal, dördüncü sırada 5.kanal, beşinci sırada 4.kanal sıralamada birbirine yakın puan aldığı ölçümlenmiş ve TV kanallarının İşaret Dili çeviri kalitesinin tespitine çalışılmıştır. 
Televizyon Haber Bültenlerindeki İşaret Dili Çeviri Hizmetine Yönelik Sağır Topluluğun Tutum ve Beklentileri

Tablo 34

Katılımcıların işaret dili çevirisi kalitesine göre sıralaması

\begin{tabular}{llc}
\hline & & İsaret dili çevirisi kalitesine göre sıralaması (max:5) \\
\hline & Kanal & Puan \\
$\mathbf{1}$ & 3.kanal & 4,10 \\
$\mathbf{2}$ & 2.kanal & 4,03 \\
$\mathbf{3}$ & 1.kanal & 3,83 \\
$\mathbf{4}$ & 5.kanal & 3,80 \\
$\mathbf{5}$ & 4.kanal & 3,69 \\
\hline
\end{tabular}

3.4.6 Sağır Katılımcılarının Akşam Haber Bülteninde Hiç Beğenmediği Televizyon Kanalının Ana Haber Bülteninde Görev Yapan Çevirmenin Çevirisi Hakkındaki Görüşleri

"Işaret dili çevirisi ile haber program yapan, hiç beğenmediğiniz televizyon kanalı hangisidir?" sorusuna 1069 kişiden, 447'si ankete cevap vermiş, diğer 622 ankete cevap vermemiştir. Cevaplayandan alınan 447 anketten 305 'i tutarsız cevaplar verdiğinden geçersiz kabul edilmiştir. Geri kalan 142 anketörün geçerli cevaplara dayanarak, anket sonucuna örneklem yöntemiyle ulaşılmıştır.

Katılımcıların İşaret dili çevirisini hiç beğenmediği TV kanallarının analiz çalışmasında, toplam 142 katılımcının seçenek sıralamasının puanlaması yapılarak, değerlendirmesi sonunda, işaret dili çevirisine yer veren TV kanallarının puan sıralamasında 3. Kanal 3.14 puan, 5 .kanal 2,83 puan, 2 .kanal 2,8 puan, 4 ,kanal 2,73 puan ve 1.kanal 2.7 puan alarak 5.sırada yer aldığı ölçülmüştür.

Tablo 35

Katılımcıların işaret dili çevirisi kalitesine göre sıralaması

\begin{tabular}{llc}
\hline \multicolumn{3}{c}{ İşaret dili çevirisi kalitesine göre sıralaması (max:5) } \\
\hline & Kanal & Puan \\
\cline { 2 - 3 } $\mathbf{1}$ & 3.kanal & 3,14 \\
$\mathbf{2}$ & $\mathbf{5 . k a n a l}$ & 2,83 \\
$\mathbf{3}$ & $\mathbf{2 . k a n a l}$ & 2,80 \\
$\mathbf{4}$ & 4.kanal & 2,73 \\
$\mathbf{5}$ & 1.kanal & 2,70 \\
\hline
\end{tabular}

3.4.7 Sağır Katılımcılarının Akşam Haber Bülteninde Genel Olarak Televizyon Kanalının Ana Haber Bülteninde Görev Yapan Çevirmenin Çevirisi Hakkındaki Görüşleri

İşaret dili çevirisine yer veren televizyon kanallarının genel ortalama analiz çalışmasında; en beğenilen ve hiç beğenilmeyen TV kanalı katılımcı sayısı ve verilen puanlar esas alınarak genel ortalama formülü geliştirilmiş ve seçeneklerinde yer alan puanlar ile TV 
kanalları sıralaması genel ortalama formülüne göre yeniden puanlamaya tabi tutulmuş ve TV kanal, puan sıralamasına Tablo 36'da yer verilmiştir.

Tablo 36

\section{Katılımcıların işaret dili çevirisini genel ortalama televizyon kanallarının analizleri}

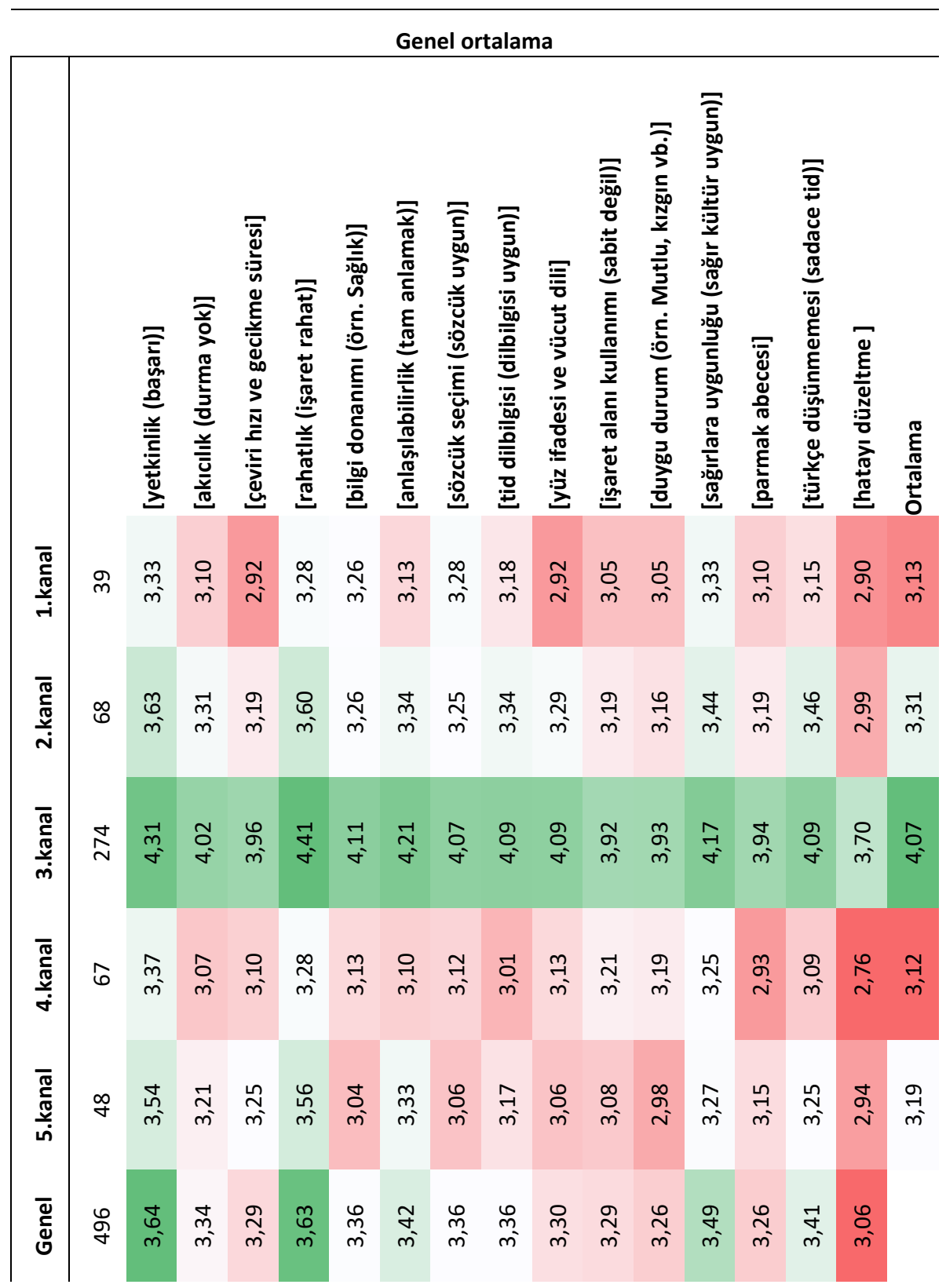


Genel ortalama formülü yardımı ile seçeneklerin puanlaması yapılmış ve bu verilere göre, genel işaret dili çevirisine yer veren beş TV kanalının kalite sıralaması yapılmıştır. Birinci sırada 3.kanalı 4,07 puan, ikinci sırada 2.kanalı 3,31 puan, üçüncü sırada 5.kanalı 3,19 puan, dördüncü sırada 1.kanalı 3,13 puan ve beşinci sırada 4.kanalı 3,12 puan aldığı ölçülmüştür.

Tablo 37.

Katılımcıların işaret dili çevirisi kalitesine göre sıralaması (max:5)

\begin{tabular}{|c|c|c|}
\hline \multicolumn{3}{|c|}{ Genel işaret dili çevirisi kalitesine göre sıralaması (max:5) } \\
\hline & Kanal & Puan \\
\hline 1 & 3.kanal & 4,07 \\
\hline 2 & 2.kanal & 3,31 \\
\hline 3 & 5.kanal & 3,19 \\
\hline 4 & 1.kanal & 3,13 \\
\hline 5 & 4.kanal & 3,12 \\
\hline
\end{tabular}

Şekil 3

Genel Ortalama Formülü (Hesap)

GENEL ORTALAMA FORMÜLÜ

GENEL ORTALAMA $=\frac{\left(x^{1} * k^{1}\right)+\left(x^{2} * k^{2}\right)}{k^{1}+k^{2}}$

$x^{1}=$ En beğendiğin puanı

$k^{1}=$ En beğendiğin katılımcı sayısı

$x^{2}=$ Hiç beğenmediğin puanı

$k^{2}=$ Hiç beğenmediğin puanı

\section{Bulgular ve Değerlendirme}

Sağır katılımcıların isteği, çevirmenin ekranda kapladığı alanın, ekranın ortalama 1/3 oranında olmasıdır. Çünkü daha küçük alan, anlama güçlüğüne sebep olmaktadır. Mevcut 5 kanalın haber program tercümanlarının ekran ölçü ortalaması 1/32'dir. Bu sebeple ekran oranı çok küçük olduğundan anlama güçlüğü yaşandığı tespit edilmiştir. Sağır katılımcıların \%27,53'ü gözlük kullanmakta olup, \%49,34'ünün evlerinde kullandığı televizyon ekran ölçüsü, 42"'den az olduğundan, anlama güçlüğü çekmelerindeki sebeplerden biri olduğu düşünülmektedir. Bu nedenle genel anlamda ekran ölçü oranının 1/32 olması yetersiz olduğunun göstergesidir. 
Sağır katılımcıların haber bültenleri değerlendirmelerinde genel eğilimleri belirlemek için, beş noktalı Likert kategorileri (1 puan = Çok kötü ile 5 puan = Çok iyi kategorileri) 1 ve 5 arasında sıralı bir ölçek olarak transkripsiyonu "memnuniyet puanı", bu puan, belirli bir değişken için belirli bir bültenden memnun olmayan katılımcıların yüzdesini temsil eder. Frekans sonuçları yüzdelere dönüştürüldü. Katılımcıların aynı haber bültende farklı çevirmenleri ayrı ayrı değerlendirdikleri durumlarda, analiz için en yüksek puan kullanılmıştır. Her değişken ve haber bülten için memnuniyet puanları Tablo 38'de verilmiştir.

Tablo 38

Katılımcıların 15 maddeye ilişkin yayınlardan memnuniyet puanları

\begin{tabular}{|c|c|c|c|c|c|c|}
\hline & 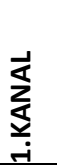 & $\begin{array}{l}\frac{\mathbb{s}}{\mathbf{d}} \\
\frac{\mathbf{d}}{\mathbf{N}}\end{array}$ & 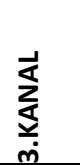 & 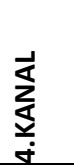 & 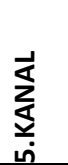 & 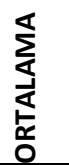 \\
\hline [Yetkinlik (başarı)] & $\begin{array}{c}\% 6 \\
7\end{array}$ & $\% 73$ & $\% 86$ & $\% 67$ & $\% 71$ & $\% 73$ \\
\hline [Akıcılık (durma yok)] & $\begin{array}{c}\% 6 \\
2\end{array}$ & $\% 66$ & $\% 80$ & $\% 61$ & $\% 64$ & $\% 67$ \\
\hline [Çeviri hızı ve gecikme süresi] & $\begin{array}{c}\% 5 \\
8\end{array}$ & $\% 64$ & $\% 79$ & $\% 62$ & $\% 65$ & $\% 66$ \\
\hline [Rahatlık (işaret rahat)] & $\begin{array}{c}\% 6 \\
6\end{array}$ & $\% 72$ & $\% 88$ & $\% 66$ & $\% 71$ & $\% 73$ \\
\hline [Bilgi donanımı (örn. sağlık)] & $\begin{array}{c}\% 6 \\
5\end{array}$ & $\% 65$ & $\% 82$ & $\% 63$ & $\% 61$ & $\% 67$ \\
\hline [Anlaşılabilirlik (tam anlamak)] & $\begin{array}{c}\% 6 \\
3\end{array}$ & $\% 67$ & $\% 84$ & $\% 62$ & $\% 67$ & $\% 68$ \\
\hline [Sözcük seçimi (sözcük uygun)] & $\begin{array}{c}\% 6 \\
6\end{array}$ & $\% 65$ & $\% 81$ & $\% 62$ & $\% 61$ & $\% 67$ \\
\hline [TiD dilbilgisi (dilbilgisi uygun)] & $\begin{array}{c}\% 6 \\
4\end{array}$ & $\% 67$ & $\% 82$ & $\% 60$ & $\% 63$ & $\% 67$ \\
\hline [Yüz ifadesi ve vücut dili] & $\begin{array}{c}\% 5 \\
8\end{array}$ & $\% 66$ & $\% 82$ & $\% 63$ & $\% 61$ & $\% 66$ \\
\hline [i̇şaret alanı kullanımı (sabit değil)] & $\begin{array}{c}\% 6 \\
1\end{array}$ & $\% 64$ & $\% 78$ & $\% 64$ & $\% 62$ & $\% 66$ \\
\hline [Duygu durum (örn. mutlu, kızgın vb.)] & $\begin{array}{c}\% 6 \\
1\end{array}$ & $\% 63$ & $\% 79$ & $\% 64$ & $\% 60$ & $\% 65$ \\
\hline [Sağırlara uygunluğu (Sağır kültür uygun)] & $\begin{array}{c}\% 6 \\
7\end{array}$ & $\% 69$ & $\% 83$ & $\% 65$ & $\% 65$ & $\% 70$ \\
\hline [Parmak abecesi] & $\begin{array}{c}\% 6 \\
2\end{array}$ & $\% 64$ & $\% 79$ & $\% 59$ & $\% 63$ & $\% 65$ \\
\hline [Türkçe düşünmemesi (sadece TiD)] & $\begin{array}{c}\% 6 \\
3\end{array}$ & $\% 69$ & $\% 82$ & $\% 62$ & $\% 65$ & $\% 68$ \\
\hline [Hatayı düzeltme ] & $\begin{array}{c}\% 5 \\
8\end{array}$ & $\% 60$ & $\% 74$ & $\% 55$ & $\% 59$ & $\% 61$ \\
\hline
\end{tabular}

Çevirmen tarafından kontrol edilen değişkenler açısından, en problemli konu kullanılan hatayı düzeltme, parmak abecesi ve duygu durumu: burada, katılımcılar 
3.kanal dışındaki tüm yayınlardan memnuniyetsizliklerini ifade etmektedir. 4.Kanal çevirmeninin TiD yetkinlik ve akıcılığın yetersiz olduğu belirlenmiştir.

Ayrıca çevirmenlerin TiD'de yeterlilikten yoksun olduğuna dair birkaç belirti vardır. (Örneğin yüz ifadesi olmaması, rol değiştirmenin ihmal edilmesi, anlaşma fiillerinin kötüye kullanılması). Hem duygusal ifade hem de dil bilgisel işaret dili çevirisi için doğal olarak oluşan işaret dillerinin ayırt edici özelliği olan manuel olmayan ifadeden çok az veya hiç faydalanılmamıştır.

Arka plan bilgisinin eksikliğini gidermek için, çevirmenlerin kanal tipi bir çevirmen modelini takip etmemeleri, ancak açıklama ve yeniden yapılandırma stratejilerini benimsemeleri önerilir yani, filtreleme veya uygun bilgi ekleme ağ geçidi normuna uymaları gerekir (bkz. Stone 2009). Bu nedenle çalışma Stone'un (2009, s. 172) Sağır çeviri normunun "doğru" bir yorum oluşturmak değil, Sağır bireyle "en uygun şekilde alakalı" bir bulgu oluşturmak olduğunu desteklemektedir.

Medya için çalışan çevirmenler, hızın çok önemli olduğunun farkında olmalıdır. Konuşmacının konuşması bittikten sonra aşırı şekilde 'takılmadan' çok hızlı olmaya gayret etmelidirler. (Kurz, 1990, 1997): "[...] medya çevirmeni, özellikle konuşmanın sonunda, konuşmacı ile kendisi arasında aşırı bir gecikme olmadan, çok hızlı olmaya gayret etmelidir [...]." (Kurz ve Bros-Brann 1996, s. 212) Aynı şey, elbette, televizyonda işaret dili çevirisi için de geçerlidir. Katılımcıların tüm haber programları için arka plan memnuniyeti, saydamın en iyi arka plan uygun olduğu yönergesiyle tutarlıdır (Tablo 20).

İşaret Dili çevirmenliği, deneyim ve birikim gerektiren profesyonel bir iş alanı olarak tanımlanabilir. Burada, çevirmenin teknik bilgisi, becerisi ve yeterli donanıma sahip olması gerekmektedir. Burada TV kanalına da önemli görevler düşmektedir.

Görünürlük sorunları; katılımcılar, çevirmenin ellerinin, yüzünün ve ağzının zayıf görünürlüğünden uygun olmayan giyim ve arka plan rengi seçiminden ayrıca çevirmeni gösteren ekran ekinin sınırlı boyutundan ve uygun olmayan konumlandırmasından bahsetmektedir.

İşaret dili çevirmeninin, sağır / işitme engelli topluluğu tarafından anlaşılması ve işaret uzatımının istenilen seviyeye ulaşmasını sağlamak için kıyafetleri ile ilgilide bazı özellikler gerekmektedir. Bedenin üst tarafındaki kıyafetlerin siyah renk (Tablo 22'deki katılımcıların \%68,45) olması ve parmaklara yüzük vb. takı takılmaması, boyun ve yüz kısmında dikkati dağıtan süs veya takı takılmaması gerekmektedir.

Televizyonda odaklama sorunu konusunda, Sağır katılımcıların çoğu $(\% 45,79)$ hem çevirmene hem de ana resme bakmaya çalışmayı zor bulduklarını ifade etmektedirler (Tablo 27).

Göz takibi kullanılan çalışma, tercümanın ağzına odaklansa da, sağır bireylerin bir haber sunucusunun veya görüşmecinin ağzına işiten bireylere göre daha az baktığını ortaya koymuştur (Wehrmeyer, 2014). Çünkü Sağır topluluğu ana resimden çok çevirmene odaklamak zorunda olduğunu ortaya koyduğu anlaşılmaktadır. 
Bir çevirmen ile ana resim arasında dikkatin bölünmesi gibi algılanan zorluk, işaret dili iletişimin daha düşük önceliğini de açıklayabilir, ancak bunun çevirmeni altyazı çevirisiyle değiştirerek çözülüp çözülmeyeceği tartışmalı bir sorudur. Örnek boyutu bu noktada genel sonuçlara varmak için çok küçük olmasına rağmen, göz izleme çalışması, Sağır bireylerin öncelikle ana resimdeki izleme bakışları ve altyazıların çok az okunması nedeniyle, çevirmene odaklandıklarını bulmuştur (Wehrmeyer, 2014).

Okuryazarlık düzeyleri ile ilgili güvenilir bir araştırma olmadığından, okuryazarlık yeterliliği tablosunda katılımcıların \%53,28'nin okuryazarlık oranlarının orta seviyeden daha düşük olduğu tespit edilmiştir (bkz. Tablo 8). Bu araştırma; bu topluluğun büyük olasılıkla ekran altyazılarını okumakta güçlük çektiğini ve teorik olarak onları bir çevirmene bağımlı hale getireceğini göstermektedir.

İzleyicilerin iletişim yeterliliği; katılımcılar işaret dili becerilerinin yetersiz olduğunu düşünürken, \%81,74'ü çevirmeninin altyazılarla değiştirilmesini istemiştir (bkz. Tablo 26.)

Sağır grupların altyazı çevirisi taleplerine rağmen, sonuçlar bir çevirmen kullanıldığında, ekrandaki metni işlemek için çok az görsel bilişsel kapasitenin kullanıldığını göstermektedir. Bu çalışma özellikle Güney Afrika'da haber programlarında kullanılan mevcut altyazı yöntemlerinin Sağırlar için yararlı olduğunu tespit etmiştir (Wehrmeyer, 2014).

Sağır Topluğu içinde potansiyel olarak düşük okuryazarlık düzeyine rağmen, altyazı çevirisi kullanılarak kullanıcı memnuniyetine ulaşmak mümkün görülmektedir. Her ne kadar altyazı çevirileri genel olarak artan bir uyum olarak görülse de (Lewis ve Jackson 2001), sonuçlar kesin değildir (örn. Cambra ve diğ. 2008) ve düşük okuryazarlık düzeylerinin, işaret dili çevirisine ihtiyaç olduğunu göstermektedir. Bu araştırma, başka yerlerdeki Sağır bireylerin işiten çevirmenlerden memnun olmadıklarına dair bulgulara ağırlık vermektedir (Stone 2009); bazı sağırların sağır çevirmenlerin de kullanılması önerisi uygun bir öneri gibi görünmektedir.

Şekil 4.

Televizyondaki Dil Tercihi

\section{Televiyondaki Dil Tercihi}

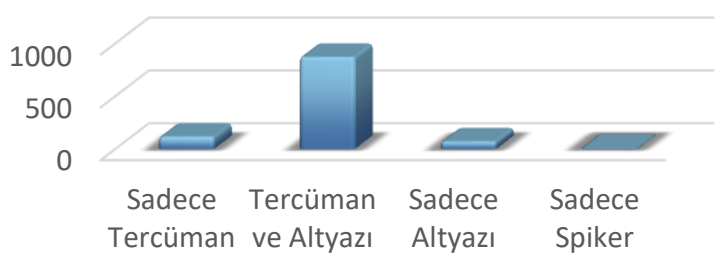


Sağır topluluğunda iki ayrı grup vardır: Birinci grup sağır olarak doğmuş olanlar, ikinci grup ise doğduktan sonra işitme bozukluğu yaşayanlardır. Bu grupların kendi düzeylerine göre ihtiyaçları ve bakış açıları farklıdır. Birinci grup temel olarak işaret dilini kullanır çünkü altyazı çevirisi kullanma yetenekleri okuma ve kavrama becerilerinin oldukça zayıf olması nedeniyle çok düşüktür. İkinci grup ise, işiten insanlarla birlikte daha fazla eğitim aldığı için okuma hızları oldukça yüksek olup, altyazı çevirisini daha rahatlıkla kullanabilir durumdadır (De Linde 1996, s. 181).

İşaret dili yeterliliği açısından, katılımcıların \%69,66'sı sağır ebeveynlerden, sağır kardeşlerden veya sağır akrabalardan alabildikleri kadar işaret dili ile iletişim kurmayı öğrenmişlerdir. Bu nedenle, iletişim dilleri işaret dili olarak sınıflandırılmıştır. Ayrıca Sağır katılımcıların \%57,4'ünün anadili Türk İşaret Dili olarak kabul edilmektedir.

Diğer önemli istatistiksel bulguya göre, \%77,53'ü kendini Sağır kültürü (Sağır topluluk) olarak tanımlamakta, \%80,33'ü ise diğer Sağır kişilerle iletişim aracı olarak Türk İsaret Dili'ni kullanmaktadır. Bu verilere göre, yetersiz işaret dili becerileri anlama eksikliğinin nedeni sayılabilmektedir.

Ankete katılan sağırların \%56,91'i haber bültenlerinde çevirmenin yanında yardımcı ve rehber çevirmen olarak "Sağır çevirmen" kullanılmasını önermektedir (Tablo 25,'Fark etmez' dağıtım ile). Yapılan çeviriler, yeterli İşaret Dili donanımına sahip olan sağır editörün kontrolüne sunulmalı, editörün ise kendi görüşlerine göre düzeltme yapması gerekmektedir.

Katılımcılara 5 kanaldan hangisini çok beğendikleri ve hiç beğenmedikleri, bu kanallardaki çevirmenleri anlayıp anlamadıkları sorulmuştur. Katılımcıların 5 kanalın haber bülteni TiD tercümanlarını beğeni ve anlama düzeyleri puan üzerinden hesaplanmıştır ( $\mathrm{N}=354)$. Sonuçlar Şekil 5 'te gösterilmektedir.

\section{Şekil 5}

Işaret dili çevirisini en beğendiği televizyon kanallarının katılımcı sayıları

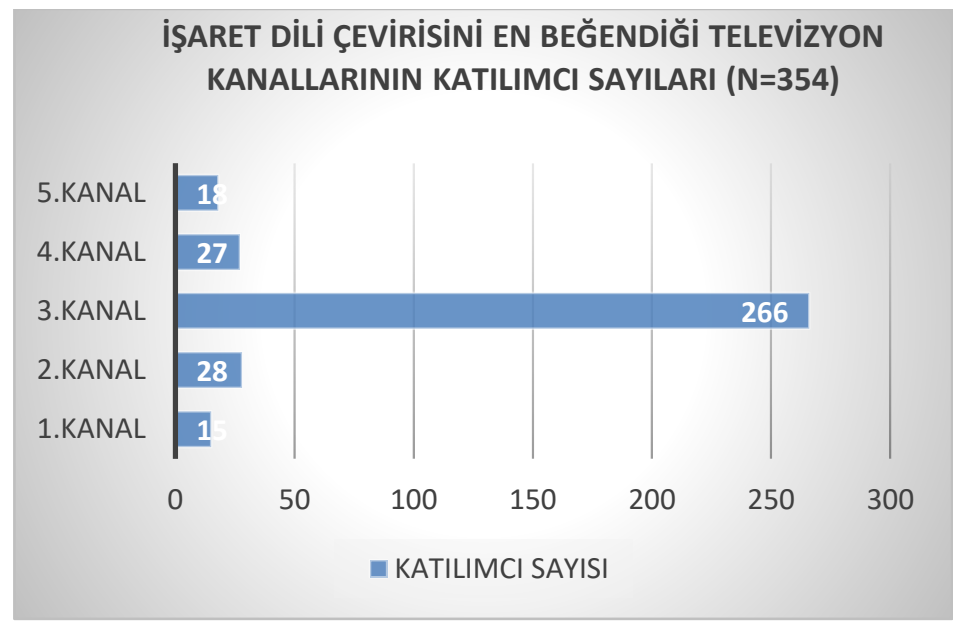


Sonuçlar, katılımcıların 3.Kanaldaki TiD tercümanını diğer yayınlarından açık ara daha iyi anladığını göstermektedir. Bu soruya katılan 354 kişiden 266 kişi $(\% 75,14)$ en çok 3.Kanalı beğenmektedir. Diğer 4 kanalı ise çok az kişi beğenmiştir.

Katılımcıların \%75,14'ünün 3.Kanalı tercih etmesinin nedeni, tercümanlarının anlaşılır olmasıdır.

\section{Şekil 6}

İşaret dili çevirisini hiç beğenmediği televizyon kanallarının katılımcı sayıları

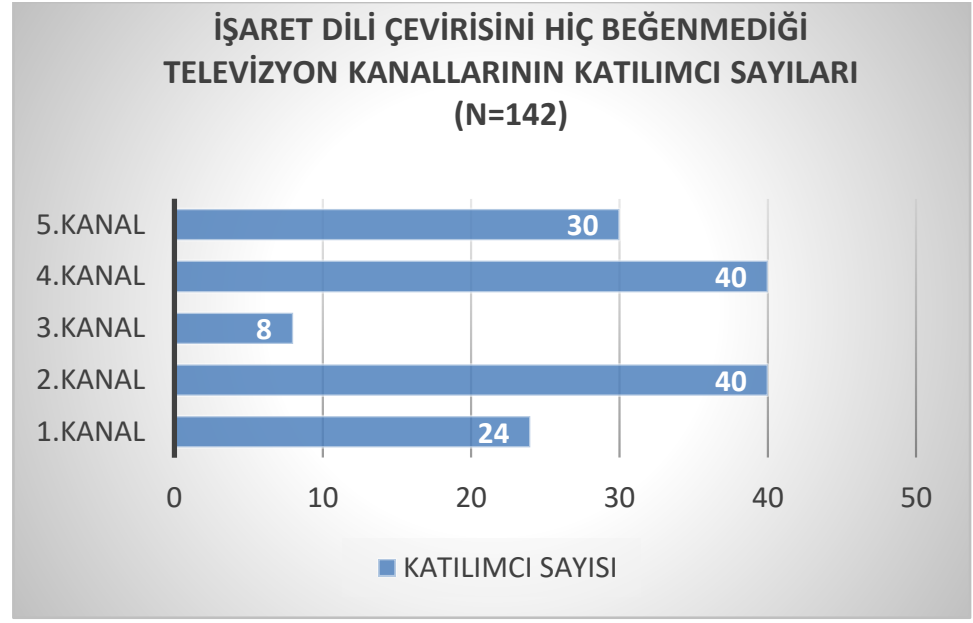

Katılımc sayılarına göre tercih sıralamasında; TiD çevirisi hiç beğenilmeyen TV kanalı tespit çalışması sonunda; 1.kanalı 24 kişi, 2.kanalı 40 kişi, 3.kanalı 8 kişi, 4.kanalı 40 kişi ve 5.kanalı 30 kişinin tercih ettiği görülmekte, Şekil $6^{\prime}$ da görüldüğü üzere, hiç beğenilmeyen TV kanalının 40 kişi ile 4 .kanal ve yine 40 kişi tercihine göre 2 . kanal olduğu ölçümlenmiştir.

Katılımcıların \%34'ü çevirmeni anlamadıklarını açık şekilde göstermektedir. Daha sonra katılımcılardan bir listeden anlamalarını engelleyen faktörleri seçmeleri istenmiştir. Bunlar ise Şekil 7'de gösterilmiştir.

Tüm çevirmenlerin genel ortalamaya göre hataları şunlardır; hatayı düzeltmeme $(3,06)$, parmak abecesi yetersizliği $(3,26)$, duygu durum yetersizliği $(3,26)$, çeviri hızı ve gecikme süresi yetersizliği $(3,29)$, işaret alanı kullanımı yetersizliği $(3,29)$ konu alt edincinden elde ettiklerinden ötürü duyulan eksikliktir. 
Televizyon Haber Bültenlerindeki İşaret Dili Çeviri Hizmetine Yönelik Sağır Topluluğun Tutum ve Beklentileri

\section{Şekil 7}

Katılımcıların TiD çevirmenliği anlamama nedenleri

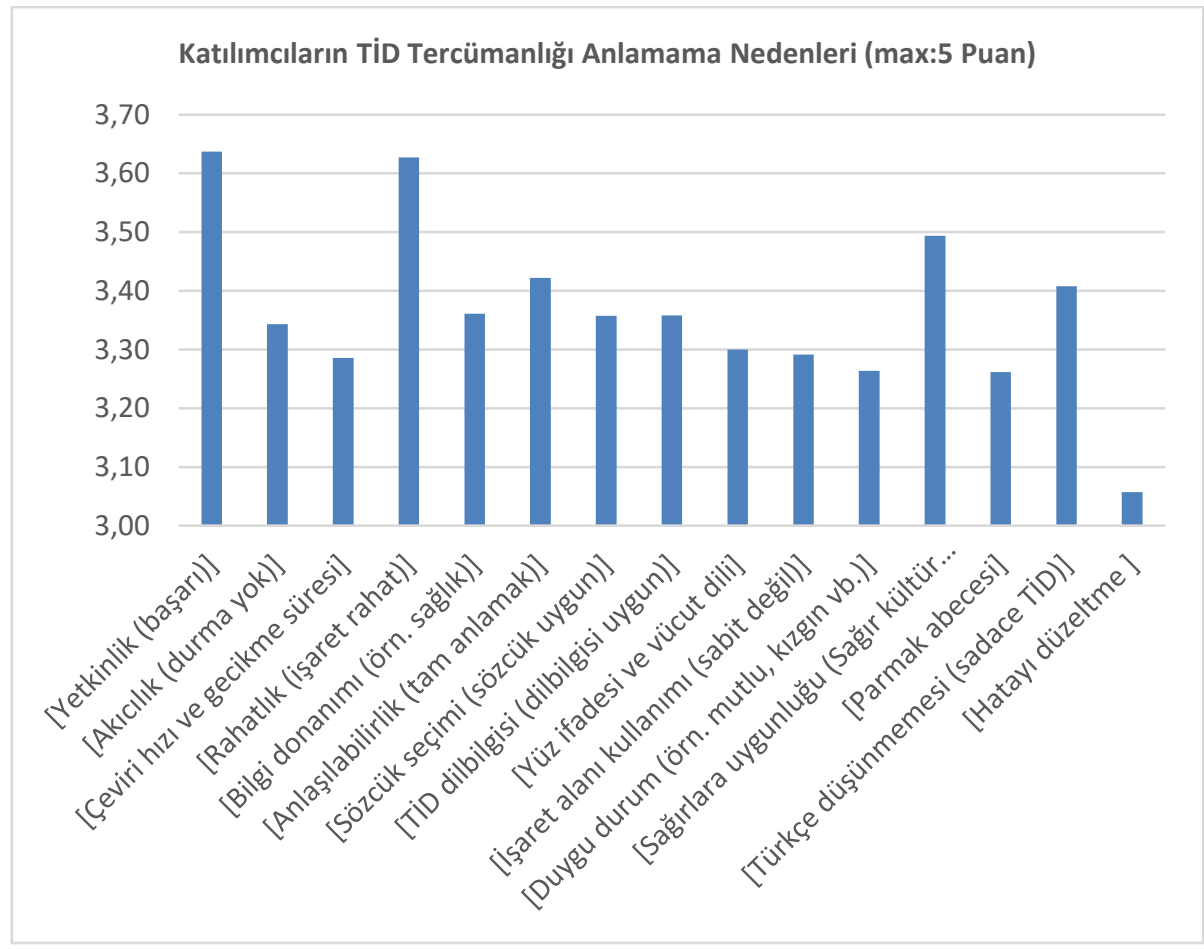

Her zaman olduğu gibi nihai kararı izleyici (sağır ve işitme engelli) topluluğu verecektir. Bu karar, çeviriden alınan verim ile doğru orantılıdır. Canlı programlar için yapılanlar dışındaki çevirilerde durum daha farklı olmakta ve görsel-işitsel metin, çevirmene çeviri öncesi iletilmeli ve çevirmen çeviri için hazırlanmalıdır. Bu durumda çevirinin çekim ile eşzamanlı yapılması halinde dahi, çevirmenin kendisini izlemesi hata ve eksiklerini düzeltmesi mümkün olabilecektir.

Özel bir sağır kanalı oluşturmak veya uzaktan kumanda ile açılabilen veya kapatılabilen bir çevirmen görüntüye sahip olması gerekmektedir.

Canlı haber yayınları için eşzamanlı işaret dili çevirisi, stres, bilgi yoğunluğu ve hız gibi faktörler nedeniyle muhtemelen en zorlayıcı çeviri türlerinden biridir (bkz. Kurz 2002) 60 dakikalık canlı haber yayınının tamamı tek bir çevirmen tarafından ele alındığından, kalitesizliğin bir başka nedeni de yorgunluk olacaktır. Bu, yorgunluğu önlemek ve hatalara eğilimi azaltmak için eşzamanlı çevirmenlerin 20-30 dakikalık vardiyalarla dönüşümlü olarak çalıştırılması önerilebilir (Moser-Mercer ve diğ., 1998). 


\section{Sonuç ve Öneri}

İşitme engelli kişilerin genel anlamda televizyonda işaret dili çevirisini anlamadıkları önceki çalışmalarda da ortaya konulmuştur (Steiner, 1998; Xiao ve Li, 2013; Xiao ve Diğ., 2015). Çevirmenlerin çeviri hızının, vücut hareketlerinin ve yüz ifadelerinin kullanılmadığını ve çevirmen tarafından kullanılan işaretlere Sağır topluluğun aşina olmadığını bu çalışmalar göstermektedir.

Yapılan ankete göre katılımcılar işaret dilinin doğal ifade edilmediği, çevirmenlerin yüz ifadesi ve mimiklerinin anlaşılır olmadığı ve benzeri nedenlerle tercüman memnuniyetsizliklerini ifade etmişlerdir. Katılımcılar, çevirmenin el hareketlerinin, yüzünün ve ağzının yeterli şekilde görünmemesinden, giyiminden, arka plan renginden ve çevirmeni gösteren ekran ekinin küçük boyutta olmasından şikâyetçi olduklarını söylemektedir. Ekranda küçük boyutlu çevirmen görüntüsü Sağır topluluğun çevirmenin çevirisini kavramasını engellemektedir. Çevirmenin giyiminin uygunsuzluğu, çevirmenin takıları gibi tercümanda aksesuar olarak bulunan objelerin hedef kitlenin dikkat dağınıklığına sebebiyet verdiği gözlemlenmiştir.

iç görüntünün çok küçük olması bireylerin kavrayışını önemli ölçüde engellemektedir. Bu nedenle, çevirmenin açıkça görülebilmesi ve izleyenlere olumlu bir katkı sağlayabilmesi için çevirmene yeterli bir alan tahsis edilmelidir. Çevirmenlerin çeviri esnasında bu özelliklere azami özen göstermeleri gerekmektedir. Çevirmenin çeviri hızına uygun davranması, el ve parmak hareketleri mimikler ve beden hareketlerini tam ve eksiksiz yapması hedef kitlenin azami ölçüde fayda sağlaması ile doğru orantılı olmaktadır

Çevirmen, çevirisini Türk işaret Diline eşzamanlı çevirmeli, bilgi içeriğini hedeflenen dile ulaşmak amacına yönelik tam ve eksiksiz yapmalıdır. Uygun el hareketleri ile doğru yapılan çeviri, çevirmenin hızını ayarlaması, hedef kitlenin çeviriden azami ölçüde faydalanma talebi isteği, çevirinin kaliteli olup olmadığının göstergesi olacaktır. Çevirmen, bilgi ve birikimli profesyonel özelliklere sahip olduğunda, yaptığı eşzamanlı çevirinin kalitesi de paralel olarak yükselecektir. El ve parmak hareketleri, mimikler ve beden hareketlerinin eşzamanlı olmasının sağlanması, profesyonel işaret dili çevirmeninden beklenen özellikler olmalıdır.

Türkiye'de bazı televizyon kanallarda, işaret dili çevirmenliği çeviri amaçlı gerçekleştirilen işaret dilinin aslında doğal Türk İşaret Dili olmadığının, daha ziyade Işaretlenmiş Türkçe olduğunun belirtilmesidir. TiD'in, konuşulan Türkçenin işaretlerle taklit edilmesine dayanan bir dil olmayıp, kendine özgü grameri bulunan ayrı bir iletişim sistemi olmasıdır. Türk İşaret Dili doğal diller olduğun için bu işler çevirmen için fazla emek gerekmektedir.

İşaret dili çevirmenleri haber yorumlanması birçok cephede çalışmalıdırlar. Özelliklede kurumsal yerlerde İşaret dili çevirisi becerileri, çok çeşitli alana özgü terminoloji ile nasıl başa çıkılacağı, parmakla yazmanın mükemmelliği ve hızlılı̆̆ı, uygun isimlerin engellenmesi ile başa çıkma, toponimler ve kalite ölçütleri ve beklenen standartların farkına varılması konularında çok fazla çalışmaya katıı kendilerini geliştirmelidirler. 
Çalışmamızda Sağır topluluğunun özellikle ayrı olarak Devlet televizyonu olan TRT’nin mevcut 14 kanalına ilave olarak Sağır/Iş̧itme engellilere özgü, içerik ve programları Sağır topluluğuna uygun olarak düzenlenmiş televizyon kanalını talep ettikleri tespit edilmiştir. Devlet kanalı olan TRT'nin kanal sayısının 14 olduğu göz önünde bulundurulduğunda, Sağır - İşitme ve Görme Engelliler için ayrı, özel bir kanal isteminin isabetli bir talep olduğu görülmektedir.

Bu çalışmanın bulguları; okuryazarlık oran düşüklüğünün Türk Sağırlar arasında hala çok önemli bir sorun olduğunu göstermekle birlikte mevcut erişilebilirlik seçeneklerinin toplumun beklentilerini ve ihtiyaçlarını karşılamadığını da ortaya koymuştur. Yine çevirmenlerin Türk İşaret Dili çevirmenliği alanlarına yönelik eğitimlere daha fazla ağırlık vermesi gerektiği ve bu alanda kendilerini geliştirmeleri gerektiği kanısına varılmıştır.

Sağır topluluğunun televizyonda kullanabilecekleri erişilebilir içeriklerin miktarını artırmak ve hedef kitlenin ihtiyaçlarını kabul etmek ve bu kitleyi tanımakla mümkündür. Erişilebilir içeriğin eksikliği giderilmelidir. Bazı sağırların sağır çevirmen olarak kullanılması önerisi de uygun bir öneri gibi görünmektedir.

Televizyon stüdyosunda profesyonel çeviri analizinin yetersiz olduğu tespit edilmekle birlikte işaret dili tercümanlarının televizyondaki çevirilere katılmadan önce uzun ve donanımlı bir eğitimden geçmeleri gerekmektedir. Yetkin düzeyde olmayan işaret dili tercümanlarının eğitimleri sırasında, farklı ortamlarda tecrübe edinebilmeleri için ve kendilerini geliştirebilmeleri adına zaman ayrılmalıdır.

Türkiye'deki tüm işaret dili tercümanlarının eğitim programları bütün yeniliklere açık bir şekilde geliştirilmeli ve yeni işaret dili çevirmenleri yetiştirmek için üniversitelerde alanlar açılmasının gerekliliği üzerinde durularak Türk işaret Dili Çevirmenliği bölümü arttırılmalıdır. İşaret dili çevirmenliği becerileri, donanımları, birikimleri ile ilgili sorunlar tercümanlık eğitim programları ile giderilerek verimlilik istenilen seviyeye çıkarılmalıdır. Öte yandan Sağır topluluk bireylerinin de eğitilmesi, bu topluluğun sorunlarının yaşam tarzının ve Sağır kültürünün bilinmesi, Sağır topluluk bireylerine özel önem verilmesi için ülkemizde yapılan araştırmaların artırılması gerekmektedir.

Bu çalışma ile Sağır topluğun erişilebilirlik ihtiyaçlarının zamanla daha fazla kabul görüp karşılanacağı ümit edilmekle birlikte küçük dahi olsa bu alana katkı sunmaya yönelik hazırlanmıştır. 


\section{Kaynakça}

Allsop, L., \& Kyle, J. G. (2008). Translating the News. English in international Deaf communication (ss. 383-401). Peter Lang International Academic Publishers.

Antonsen, S. (2006). A live interpreter channel in Norway: NRK1 Tegnspråk/NRK1 Sign Language. Proceedings of the Inaugural Conference of the World Association of Sign Language Interpreters. Coleford, Gloucestershire: Douglas McLean.

Avrupa Birliği Görsel-işitsel Medya Hizmetleri Yönergesi, 15.4.2010, https://www.rtuk.gov.tr/avrupa-birligi-gorsel-isitsel-medya-hizmetleriyonergesi/4934/3897/avrupa-birligi-gorsel-isitsel-medya-hizmetleri-yonergesi-1542010tr-I-951.html

Baker-Shenk, C. L., \& Padden, C. (1979). American Sign Language: A look at its history, structure, and community. TJ Pub Incorporated.

Birleşmiş Milletler Engelli Hakları Sözleşmesi, 13 Aralık 2006, http://www.tiemf.org.tr/arsiv /mevzutlar/bm_engellihaklarisozlesmesi.pdf.

Bontempo, K., \& Napier, J. (2011). Evaluating emotional stability as a predictor of interpreter competence and aptitude for interpreting. Interpreting, 13(1), 85-105.

Brien, (1992). Dictionary of British Sign Language/English. Faber and Faber, London,Boston

Cambra, C., Silvestre, N., \& Leal, A. (2008). Eğitimin çeşitli kademelerindeki işitme engelli öğrencilerin televizyon mesajlarını anlamaları. American Annals of the Deaf , 153 (5), 425434.

Çeviri Derneği (2020). https://portal.myk.gov.tr/index.php?dl=Yeterlilik\%2F2481\%2FSON _TASLAK_PDF_20200504_191546.pdf\&fileName=20UY0407-6++Rev+00+\%C4\%B0\%C5 \%9Faret+Dili+\%C3\%87evirmeni\&option=com_yeterlilik

Dikyuva, H., Makaroğlu, B., \& Arık, E. (2015). Türk işaret dili dilbilgisi kitabı. Aile ve Sosyal Politikalar Bakanlığı Yayınları

Forestal, Eileen (2005). "The Emerging Professionals: Deaf Interpreters and Their Views and Experiences on Training". M. Marschark, R. Peterson and E.A. Winston (eds). Sign Language Interpreting and Interpreter Education: Directions for Research and Practice. Oxford: Oxford University Press, 235-258

Gile, D. (1995). Fidelity assessment in consecutive interpretation: An experiment. Target. International Journal of Translation Studies, 7(1), 151-164.

Gök, S. (1958). Dünyada ve Türkiye'de sağır dilsiz okulları tarihçesi ve eğitim sistemleri. Hüsnü Tabiat Basımevi.

Gökçe, i. (2018). Accessibility of the Deaf to the television contents through sign language interpreting and SDH in Turkey. Dokuz Eylül Üniversitesi Edebiyat Fakültesi Dergisi, 5(1), 109-122.

Hogg, L. (2011). Funds of knowledge: An investigation of coherence within the literature. Teaching and Teacher Education 27, 666-677. DOI: 10.1016/j.tate.2010.11.005

Inghilleri, M. (2005). Mediating zones of uncertainty: Interpreter agency, the interpreting habitus and political asylum adjudication. The Translator, 11(1), 69-85. 
Jackson, D. W., Paul, P. V., \& Smith, J. C. (1997). Prior knowledge and reading comprehension ability of deaf adolescents. Journal of Deaf Studies and Deaf Education, 2, 172-184.

Kaya, M. (2019). RTÜK - Sağır, İşitme ve Görme Engellilerin Medya Hizmetlerine Erişiminin İyleştirilmesi Çalıştayı Paneli. Yayımlanmamış konuşma metni.

Kellett Bidoli, C. J. (2010). Interpreting from speech to sign: Italian television news reports., The Interpreters' Newsletter, 15, 173-191.

Kurz, I. (1990). Overcoming language barriers in European television. D. Bowen ve M. Bowen (Ed.) Interpreting Yesterday, Today and Tomorrow (ss. 168-175). John Benjamins Publishing.

Kurz, I. (1997). Getting the message across-Simultaneous interpreting for the media. Benjamins Translation Library, 20, 195-206.

Kurz, I., \& Bros-Brann, E. (1996). L'terprétation en doğrudan pour la télévision. Les transferts linguistiques dans les medias audiovisuels, Villeneuve d'Ascq, Presses Universitaires du Septentrion, 207-216.

Kurz, I., \& Mikulasek, B. (2004). Television as a source of information for the deaf and hearing impaired. Captions and sign language on Austrian TV. Meta: Journal des traducteurs/Meta: Translators' Journal, 49(1), 81-88.

Kurz, K. B., \& Langer, E. C. (2004). Student perspectives on educational interpreting: Twenty deaf and hard of hearing students offer insights and suggestions. E. A. Winston (Ed.), Educational interpreting: How it can succeed (ss. 9-47). Gallaudet University Press.

Kyle, J. (2007). Sign on television: Analysis of data based on projects carried out by the Deaf Studies Trust 1993-2005. Ofcom.

https://www.ofcom.org.uk/_data/assets/pdf_file/0015/50181/deafstudies_annex.pdf

Kyle, J. G., Kyle, J., Woll, B., Pullen, G., \& Maddix, F. (1988). Sign language: The study of deaf people and their language. Cambridge University Press.

Kyle, J., \& Allsop, L. (1982). Deaf people and the community: Final report to the Nuffield Foundation. School of Education Research Unit, University of Bristol.

Kyle, J.G., \& Woll, B. (1985). Sign language: The study of deaf people and their language. Cambridge. UK: Cambridge University Press.

Ladd, P. (2003). Understanding deaf culture: In search of deafhood. Multilingual Matters.

Leeson, L. (2005). Making the effort in simultaneous interpreting: Some considerations for signed language interpreters. T. Janzen (Ed.), Topics in Sign Language Interpreting, 51-68. John Benjamins.

Locker, R. (1990). Lexical equivalence in transliterating for deaf students in the university classroom: Two perspectives. Issues in Applied Linguistics, 1(2), 167-195.

Marucha, A. N. (2016). Media integration of Kenya sign language during television newscasts in Kenya (Yayınlanmamaıs doktora tezi), University of Nairobi.

McKee, R. (2014). Breaking news: Sign language interpreters on television during natural disasters. Interpreting, 16(1), 107-130. 
Napier, J., \& Barker, R. (2004). Accessing university education: Perceptions, preferences, and expectations for interpreting by deaf students. Journal of deaf studies and deaf education, 9(2), 228-238.

Napier, J., \& Rohan, M. J. (2007). An invitation to dance: Deaf consumers' perceptions of signed language interpreters and interpreting. Translation, sociolinguistic, and consumer issues in interpeting (ss. 159-203). Gallaudet University Press.

Neves, J. (2007). Of pride and prejudice: The divide between subtitling and sign language interpreting on television. Leeson, Lorraine \& Graham Turner (Eds). The Sign Language Translator \& Interpreter (SLTI), 1(2), 251-274.

Okyayuz, A. Ş. (2019a). Görsel-işitsel çeviri ve engelsiz erişim. Siyasal Kitabevi.

Okyayuz, A. Ş. (2019b). Görsel-işitsel çeviride yenilikçi araştırma alanlarına örnekler ve Türkiye'de araştırma boşluklarına bir bakış. Language and Literature, 14(3), 1395-1415.

Okyayuz, A. Ş., \& Kaya, M. (2020). Disability and the implication of coaccessibility: a case study on accessibility to the media in Turkey. Media, Culture \& Society, 42(6), 987-1002.

Okyayuz, A. Ş., Fırat, B., \& Oral, Z. (2017). Sağırların ayrıntılı altyazı ve işaret dili çevirisiyle görselişitsel ürünlere erişimine ilişkin anket çalışması. Unpublished Survey.

Okyayuz, Ş., \& Kaya, M. (2017). Görsel-işitsel çeviri eğitimi. Siyasal Kitabevi.

Pöchhacker, F. (2007). Coping with culture in media interpreting. Perspectives, 15(2), 123-142.

Rudvin, M. (2002). How neural is neural"? Issues in interaction and partecipation in community interpreting. G. Garzone (ed.). Perspectives on Interpreting, 33, 217- 233.

Ruuskanen, D. D. (1996). The effect of pragmatic factors on the definition of equivalence in translation. Language sciences, 18(3-4), 883-895.

Sönmez, Ö. F., Karatekin, K., \& Merey, Z. (2013). Ulusal televizyon kanallarında engelli hakları. Electronic Turkish Studies, 8(8), 2073-2095.

Steiner, B. (1998). Signs from the void: The comprehension and production of sign language on television. Interpreting, 3(2), 99-146.

Stone, C. (2005). Deaf translators on television: Reconstructing the notion of'interpreter'. University of Bristol, Department of Sociology.

Stone, C. (2009). Toward a Deaf translation norm. Gallaudet University Press.

Stone, C. (2007) Deaf Access for Deaf People: The Translation of the Television News from English into British Sign Language. In Jorge Díaz Cintas, Pilar Orero and Aline Remael (Eds.), Media for All: Subtitling for the Deaf, Audio Description, and Sign Language (ss. 71-88). Rodopi.

Stratiy, A. (2005). Best practices in interpreting: a Deaf community perspective. T. Janzen (Ed.), Topics in signed languages and interpreting: theory and practice (ss. 231-250). John Benjamins.

Tyler, M. D., Jones, C., Grebennikov, L., Leigh, G., Noble, W., \& Burnham, D. (2009). Effect of caption rate on the comprehension of educational television programmes by deaf school students. Deafness \& Education International, 11(3), 152-162.

Wehrmeyer, E. (2015). Comprehension of television news signed language interpreters: A South African perspective. Interpreting, 17(2), 195-225 
Wehrmeyer, J. (2014). Eye-tracking Deaf and hearing viewing of sign language interpreted news broadcasts. Journal of Eye Movement Research, 7(1), 1-16. doi:10.16910/jemr.7.1.3

Wehrmeyer, J. E. (2013). A critical investigation of Deaf comprehension of signed TV news interpretation (Yayınlanmamış doktora tezi), University of South Africa.

Witter-Merithew, A., Johnson, L. J., \& Russell, D. (2005). Toward competent practice: Conversations with stakeholders. Registry of Interpreters for the Deaf, Incorporated.

Woll B. (1991) Sign Language on Television: Final Report to Channel 4, Bristol, Centre for Deaf Studies.

Xiao, X., \& Li, F. (2013). Sign language interpreting on Chinese TV: a survey on user perspectives. Perspectives, 21(1), 100-116

Xiao, X., \& Yu, R. (2009). Survey on sign language interpreting in China. Interpreting, 11(2), 137163.

Xiao, X., Chen, X., \& Palmer, J. L. (2015). Chinese Deaf viewers' comprehension of sign language interpreting on television: An experimental study. Interpreting, 17(1), 91-117. 